\title{
TITLE VII AND THE COMPLEX FEMALE SUBJECT
}

\author{
Kathryn Abrams*
}

There are so many roots to the tree of anger
that sometimes the branches shatter
before they bear.
Sitting in Nedicks
the women rally before they march
discussing the problematic girls
they hire to make them free.
An almost white counterman passes
a waiting brother to serve them first
and the ladies neither notice nor reject
the slighter pleasures of their slavery.
But I who am bound by my mirror
as well as my bed
see causes in color
as well as sex.
and sit here wondering
which me will survive
all these liberations.

- Audre Lorde ${ }^{1}$

One strength of Title $\mathrm{VII}^{2}$ has been its capacity to accommodate the changing conceptions of discrimination and the self-conceptions of subject groups. In the first decades of its enforcement, advocates have raised - and courts have endorsed - a range of contrasting conceptions in order to broaden the employment opportunities of protected groups. This flexibility is particularly evident with respect to women.

The most recurrent, and most influential, theory has been an "equality" or "sameness" theory of discrimination. This theory describes women as substantially similar to men in most respects ger-

* Professor of Law, Cornell Law School; Associate Professor, Cornell Program on Ethics \& Public Life. B.A. 1980, Harvard-Radcliffe; J.D. 1984, Yale. - Ed. I would like to thank Martha Chamallas and Michael Harper for their helpful and thought-provoking comments on an earlier draft of this essay. I would also like to thank Stewart Schwab for useful conversations on the subject of this essay.

1. Audre Lorde, Who Said It Was Simple, in undersong: Chosen Poems Old and New 95 (rev. ed. 1992).

2. Civil Rights Act of 1964, Pub. L. 88-352, tit. VII, 78 Stat. 241, 253-66 (codified as amended principally at 42 U.S.C. $\$ \$ 2000$ e to 2000 e-17 (1988 \& Supp. III 1992)). 
mane to employment; it describes discrimination as the prejudiced or erroneous failure to recognize this similarity, resulting in treatment of women as inferior, unable, or otherwise different from the paradigmatic male denizens of the workplace. A second theory, which has surfaced in cases involving pregnancy or gender-role expectations, highlights ways in which women differ from men. It notes that women's participation in the workforce is shaped by biological differences related to gestation and childbirth and by gender-role expectations that affect behavior in the workplace and require the integration of conflicting responsibilities of work and family. According to this "difference" theory, discrimination results from the failure to recognize these differences, to anticipate the devaluative light in which employers may view them, or to accommodate them in structuring the demands of workplaces. A third theory, which has been particularly influential in cases involving sexual harassment, characterizes discrimination as the devaluative sexualization or derogation of women in the workplace. Whether employers are expressing overt hostility or manifesting "sex role spillover,"3 harassment characterizes women primarily as sexual objects, or as objects of sex-based derision, rather than as competent workers. Women themselves are shaped by the pervasiveness of sexual objectification inside and outside the workplace; they are likely to perceive sexualized conduct as more of a threat to their professional and personal security than would their male counterparts, and they may feel less able to complain or take action against the harasser.

Despite outward differences, however, the theories that have informed Title VII enforcement also reflect important similarities. Each characterizes the identity on the basis of which women claim relief as comparatively simple and fixed. It may be biologically given, as with some difference theories; or emerge from social construction, as with sexual objectification or other difference theories; or arise from some unspecified combination of forces, as with equality theory. But regardless of the source of this identity, what it means to be a woman is, in the context of each of these theories, a fairly straightforward proposition. The defining characteristics can be simply stated, generally through comparison to men; they apply with relative consistency to the group in question, and they do not shift in valence or emphasis over time or in response to differing circumstances. The discrimination women suffer is similarly uni-

3. This term is taken from Barbara A. Gutek, Sex AND the Workplace 15-16 (1985). See infra note 213. 
tary, in that it rests on a particular understanding or set of related understandings that operate consistently across the membership of the victim group.

Title VII enforcement may face a greater challenge as it responds to a more recent series of accounts of gender discrimination - those that emphasize the complex, intersectional character of the female subject ${ }^{4}$ and the variability of the discriminatory animus that subject encounters. These accounts, as they have emerged in feminist theory and political practice, reflect not only a concern about the conceptual inadequacy or instability of categories but also a concern with the political stakes of unitary, or categorical, representations of women. Categorical representations have privileged the perspectives of the most powerful women; they have fueled the mobilization of negative stereotypes and prevented the recognition of ambivalence that might ground alliances with other groups.

Cases highlighting complex subjectivity have increasingly appeared in court, as persons claiming intersectional forms of discrimination, or manifesting identities that are ambivalent in relation to the existing statutory categories, have sought relief under Title VII. Many courts have been unwilling to accommodate these understandings within Title VII doctrine, requiring that claimants disaggregate and choose among the elements of their identities; others have awarded relief to complex claimants but failed to give an account of the discrimination they face that would help integrate such claims into the mainstream of Title VII doctrine. One factor contributing to these failures is that courts have made little effort to make explicit either the assumptions that underlie complex subjects' claims of discrimination or the barriers that Title VII doctrine currently presents to them. ${ }^{5}$

4. For purposes of this essay, I understand subjectivity to have both an external element and an internal element. The external element reflects concerns such as what kind of subject a particular person or legal claimant appears to be, what kind of influences have shaped her, and what kinds of groups can lay claim to her loyalties or affiliations. The internal element concerns how she perceives or responds to particular circumstances or behaviors, as well as the features of the perceptual framework through which she views the world. In other words, the term subject may denote an actor or agent - the external element - or the locus of subjective perception - the internal element.

5. These assumptions and the contrasting assumptions that create barriers under Title VII are discussed infra in Part III. One example of such an assumption is the complex claimant's position that the group-based characteristics targeted by discrimination may be biologically given, formed by social construction, or both. Title VII doctrine, in contrast, views groupbased characteristics subject to protection - for example, race or gender - as biologically given. 
After exploring recent doctrinal efforts to respond to complex claimants, I address these questions and assess the prospects of change. Although the unitary or categorical notions of group identity under which Title VII has historically been enforced might run counter to this goal, two other features of Title VII jurisprudence will assist proponents of interpretive change: the demonstrated capacity of Title VII doctrine to accommodate diverse accounts of discrimination, and the integration of assumptions that will be useful to complex claimants into existing bodies of Title VII doctrine, such as sexual harassment, disparate impact, and disparate treatment law relating to stereotypes.

\section{The Emergence of a Complex Female Subject}

\section{A. Antecedents}

The claim that "second wave" feminists embraced a notion of a unitary, identitarian female subject should not be overstated. ${ }^{6}$ The singular conceptualizations of women's perception or experience that marked early feminist efforts were partly strategic; to highlight the voices that had been excluded, it was often useful to streamline the message and downplay complexity or contradiction. ${ }^{7}$ Moreover, even when unitary conceptions were not attributable solely to strategic ends, they often held the seeds of their dissolution. Accounts that hypothesized the social construction of gender ${ }^{8}$ at least implicitly raised the question of why women were not subject to other constructive influences as well. In addition, the juxtaposition of any two such theories - the difference and dominance theories, for example - revealed that even one's identity "as a woman" could be shaped by multiple images, norms, and influences.

Nonetheless, it is difficult to deny the tendency in many earlier feminist theories toward singular characterizations of female subjects. Equality theory's designation of women as "similar to men" involved little specification of women's subjectivity, yet it implicitly

6. The term second wave usually refers to the revival of interest in women's rights and equality ignited in the 1960s and 1970s by the work of Betty Friedan, Gloria Steinem, Germaine Greer, Kate Millet, and others. Here I extend the term to cover academic movements in feminism including equality, difference, and dominance theories.

7. For example, feminists who sought to demonstrate that the victim's perspective had been excluded from rape adjudication emphasized the similarities rather than the differences among rape victims' perspectives on the act. See, e.g., Susan Estrich, Rape, 95 YALE L.J. 1087 (1986).

8. See, e.g., Catharine MacKinnon, Feminism Unmodified (1987) (presenting a dominance theory emphasizing social construction through male sexual violence); SARA RuDdick, MATERNAL ThinKING (1989) (presenting a difference theory emphasizing social construction through the experience of ongoing care for a dependent other). 
invoked the Enlightenment image of the presocial, rational, selfdirecting subject - a subject whose essential unity and coherence were distinguishing and influential characteristics. Difference and dominance theories, whose subjects were constituted through social construction, offered comparably singular accounts: the woman manifesting the "ethic of care" was constituted predominantly by her domestic commitments and the social expectations that reinforced them; the woman described by dominance theory was forged by the relentless and violent sexualization to which she was subjected. ${ }^{10}$ Moreover, some of these theorists struggled to present their theses as the singular and correct explanation of women's condition, explicitly opposing the kind of juxtaposition that might highlight the construction of a complex subjectivity. ${ }^{11}$

Several concurrent developments helped to move feminist legal scholars and advocates toward expression of a more complex female subjectivity. One was a shift in the strategic considerations that had encouraged the tendency toward unitary depictions. Opponents of change began to use singular characterizations of women's perceptions or experiences to stigmatize and stereotype women claiming injury. The difference-based imagery of domestic-

9. This term originated in Carol Gilligan, In a Different Voice (1982). On my reading, I am prepared to accept her claim that she did not intend to link such an ethic in a rigid way to female (biological) sex or (social) gender. See id. at 2. However, many subsequent interpreters of Gilligan's work, both sympathetic and critical, have understood her to make a strong claim about the connection between women and the care ethic. See Carrie Menkel-Meadow, Portia in a Different Voice: Speculation on a Women's Lawyering Process, 1 BERKELEY WOMEN's L.J. 39 (1985) (providing a sympathetic account interpreting Gilligan as establishing a strong link); Joan Williams, Deconstructing Gender, $87 \mathrm{MrCH}$. L. Rev. 797 (1989) (providing a critical account interpreting Gilligan as establishing a strong link).

10. Catharine MacKinnon's writings reflect this idea:

[S]exuality [i]s a social construct of male power: defined by men, forced on women, and constitutive of the meaning of gender.

....

... So many distinctive features of women's status as second class - the restriction and constraint and contortion, the servility and the display, the enforced passivity, the humiliation - are made into the content of sex for women.

Catharine A. Mackinnon, Toward a Feminist Theory of the State 128-30 (1989).

11. Catharine MacKinnon is the best example of this tendency. Her choice of the title Feminism Unmodified for her 1987 book, for example, denotes her belief that her theory constitutes feminism, period, and that efforts to theorize women's oppression differently constitute modifications that detract from the effort by departing from that essential understanding. Other indicia of this belief are evident at various points throughout her writing. See id. at 173 (describing her characterization of rape as "[ $[$ ] he view that derives most directly from victims" experiences, rather than from their denial"). For an interesting discussion of the reasons MacKinnon rejects the possibility of a pluralism among feminists, see Christine A. Littleton, Feminist Jurisprudence: The Difference Method Makes, 41 SrAN. L. REv. 751, 75463 (1989) (reviewing Feminism Unmodified). 
ity was used to ascribe segregated workforces to women's choice. ${ }^{12}$ The mainstream media transformed the dominance-tinged account of "learned helplessness" into images of pathologically passive women, ${ }^{13}$ and unsympathetic courts used it to deny child custody to battered mothers. ${ }^{14}$ The earlier - and continuing - need to articulate readily intelligible images of women was supplemented by a contrasting need to show heterogeneity, within the group and within individual women, to resist the damaging manipulation of unitary understandings. ${ }^{15}$ Yet this very interpretation of and response to the problem by feminist activists was itself informed by contemporaneous developments in feminist theory.

One was the movement within social theory from structuralist to poststructuralist accounts of social construction. Structuralist theories had challenged liberal phenomenological accounts of the subject by introducing descriptions of that subject - its actions and, indeed, its awareness - as being determined or produced by structures of language or economics. ${ }^{16}$ Poststructuralist theories retained the structuralist challenge to the autonomy of individual subjectivity, while exposing the contingency or indeterminacy of structural influence. Rather than characterizing the subject as the product or artifact of one underlying structure, poststructuralists described the subject as a "locus" at which multiple structures intersect in variable, local patterns. ${ }^{17}$

12. See, e.g., EEOC v. Sears, Roebuck \& Co., 628 F. Supp. 1264 (N.D. Ill. 1986), affd., 839 F.2d 302 (7th Cir. 1988). For a thoughtful discussion of this tendency, particularly in relation to the Sears case, see Williams, supra note 9.

13. See Martha Mahoney, Legal Images of Battered Women: Redefining the Issue of Separation, 90 Mich. L. REV. 1, 4 (1991).

14. Id. at 49.

15. Complex or nonunitary depictions are not, of course, a foolproof political strategy. They can be manipulated as well by opponents who claim that women "want it both ways" or that the difficulty of generalizing about women's experiences suggests that making changes to benefit women is either unnecessary or impossible. In the particular context discussed above, however, unitary images have created a political liability to which more complex images present at least a partial solution.

16. I use the term liberal phenomenological to refer to accounts that accept as an unreduced point of departure the subject's experience of its own intentionality and consciousness. Cf. Thomas C. Heller, Structuralism and Critique, 36 STAN. L. REv. 127, 135 n.14 (1984) (defining existential and transcendental phenomenology). Paradigmatic structuralist theorists who are understood to have deconstructed this account of the subject by introducing the notion of structural determination include Marx, Saussure, and Levi-Strauss. See Karl Marx, Capital (Frederich Engels ed. \& Samuel Moore \& Edward Aveling trans., Foreign Language Publishing House 1961) (1867); Ferdinand de Saussure, Course iN General Linguistics (Charles Bally et al. eds. \& Ray Harris trans., Gerald Duckworth Co. 1983) (1916); Claude Levi-Strauss, Myth and Meaning (1978); Claude Levi-Strauss, The RAW AND the CoOKed (John Weightman \& Doreen Weightman trans., 1969).

17. Representative poststructuralist theorists include JacQues Derrida, Of Gram. matology (Gayatri C. Spivak trans., 1976); Michel Foucault, The History of Sexual. 
A second development, which was informed by and dovetailed with the critique of structuralism, was the antiessentialist critique within feminist theory. Although this critique is widely credited with illuminating the diversity of women as a group, it also had important implications for the depiction of the subjectivity of individual women. Because of its importance for the development of a complex account of subjectivity in feminist legal theory, I will examine this factor in greater detail. ${ }^{18}$

\section{B. Antiessentialist Critiques in Feminist Legal Theory}

Antiessentialist critiques penetrated the world of feminist practice long before they entered the realm of scholarship. Sojourner Truth's challenge to the use of domestic imagery to convey the experience of all women dates back to the nineteenth century. ${ }^{19}$

ITY (Robert Hurley trans., 1980); Jean-Francois Lyotard, The Postmodern Condition (Geoff Bennington \& Brian Massumi trans., 1984). Some poststructuralists also identify a school of left poststructuralism, which attempts to turn the multiplicity and indeterminacy of structural influence to progressive political purposes. See, e.g., ERNESTO LeCLAU \& Chantal Mouffe, Hegemony \& Socialist Strategy: Towards a Radical DemoCRATIC POLITICS 186-87 (1985).

18. I also emphasize what I will call the "antiessentialist" critique because it is more concerned with the negative social consequences of unitary categorization, as well as with the indeterminacy or instability of categorization as such. I draw this distinction from the work of Kimberle Crenshaw, who identifies her own efforts as focusing primarily on the social consequences of categorization. See Kimberle Crenshaw, Mapping the Margins: Intersectionality, Identity Politics, and Violence Against Women of Color, 43 Stan. L. Rev. 1241, 1298 (1991) ("[F]or the most part, the dimension of racial domination that has been most vexing to African Americans has not been the social categorization as such, but the myriad ways in which those of us so defined have been systematically subordinated."). In highlighting the circumstances of the categorically ambivalent claimant, I may focus more on the incoherence of unitary categories than does Crenshaw. Yet even this focus is the product, not of an interest in categorical incoherence as such, but of a concern with the unjustified marginality, even within ostensibly progressive legal reform efforts, of those who are categorically ambivalent. I should also note that in my use of the term antiessentialist to describe legal feminists of color who have challenged the exclusory and false universalism of some mainstream feminist legal theories, I depart from the usage of Crenshaw, who describes antiessentialists as analogous to postmodernists and juxtaposes "intersectional" feminism to both. See id. at 1296. My use of the term antiessentialist as denoting one who is concerned not simply with the descriptive accuracy but with the political consequences of categorical representations is more consistent with that of Angela Harris, who targets from the standpoint of black feminists what she describes as the "essentialism" of Catharine MacKinnon and Robin West, although she describes her own approach as "postessentialist" or embodying "multiple consciousness." See Angela P. Harris, Race and Essentialism in Feminist Legal Theory, 42 STAN. L. REv. 581, 591-608 (1990).

19. Sojourner Truth addressed the second annual convention of the women's rights movement. Sustaining the hostile shouts of white feminists, who thought it unfit that a black woman address the gathering, she spoke in response to a man who argued that women were too weak to perform their share of manual labor. Her words, now famous, demonstrated that the nineteenth-century social imagery of domesticity had never applied to black women:

Dat man ober dar say dat women needs to be helped into carriages, and lifted ober ditches, and to have de best places ... and ain't I a woman? Look at me! Look at my arm! ... I have plowed, and planted, and gathered into barns, and no man could head 
Women of color and lesbians who had not heard their experiences described in early consciousness-raising sessions raised dissenting voices within the "second wave" feminist movement.20 By the late 1970 s and early 1980s, arguments stressing the variety and erasure of many women's experiences had entered the field of feminist scholarship as well. Scholars described a range of ways in which mainstream feminist theorists had characterized the perspectives of a privileged subset of women - those who were white, straight, and middle class - as the vantage point of women as a group. The critique challenged the descriptive, epistemological, and ethical dimensions of feminist theory. The descriptions of "women's" experience or perception that had become commonplace within feminist theory were exposed as perilously incomplete; ${ }^{21}$ the revealed solipsism of mainstream accounts also cast doubt on the sufficiency of experiential argumentation, of the revaluation of rationality, and of other epistemological and ethical innovations. ${ }^{22}$ The antiessentialist critique, finally, exposed the exclusionary power dynamic that underlaid one kind of feminist unity; the unity that characterized accounts of women as a group had been achieved through the erasure or marginalization of the lives of less privileged women.

Challenging unitary characterizations of women as a group did not, in and of itself, commit feminists to a multifocal account of female subjectivity. One could describe a nominal group women, composed of discrete subgroups shaped primarily by their own constitutive influences and boasting their own largely unitary identities. Such a development was, in fact, the spectre used by scholars and activists to resist the critique. Some feminist scholars worried that

me - and ain't I a woman? I could work as much as any man (when I could get it), and bear de lash as well - and ain't I a woman?

BELL HOOKS, AIN'T I A WOMAN 159-60 (1981) (quoting Sojourner Truth).

20. See, e.g., BELl hOOKS, FEMINIST THEORY: FROM MARGIN TO CENTER (1984) (discussing the marginalization or exclusion of black women in the contemporary feminist movement); Carole S. Vance, Pleasure and Danger: Towards a Politics of Sexuality, in PLeAsure and Danger: Exploring Female Sexuality (Carole S. Vance ed., 1984) (noting that feminism may submerge or thwart exploration of women's sexuality, particularly by lesbians and other "sexual minorities").

21. Angela Harris notes, for example, that depictions of women as pedestalized "angels of the house" have never described the lives of black women; nor, moreover, do accounts of rape that emphasize assault by strangers or neglect the use of rape charges as a means of terrorizing and disciplining black men adequately reflect black women's experience. Sce Harris, supra note 18, at 595-96, 598-601.

22. See, e.g., Elizabeth V. Spelman, The Virtue of Feeling and the Feeling of Virtue, in FEminist Ethics 213 (Claudia Card ed., 1991) (noting the incompleteness of a feminist ethical theory that fails to attend to pain women have inflicted on each other); Katha Pollitt, Marooned on Gilligan's Island: Are Women Morally Superior to Men?, NATION, Dec. 28, 1992, at 799 (providing a critique of the essentialism in the moral and epistemological theories of Carol Gilligan and Sara Ruddick). 
the constructive force of gender would be lost in the proliferation of influences and categories; ${ }^{23}$ others claimed that emphasizing the diverse, nonintersecting aspects of women's subjectivity would impede coalition and make efforts to seek concrete relief impossible. ${ }^{24}$ Those who offered these arguments, however, failed to glimpse all the ramifications of the critique. A critique that began by emphasizing the diversity of women as a group ultimately highlighted the heterogeneity and complexity of individual female subjectivity as well. To illustrate this connection, I will turn briefly to the work of two antiessentialist theorists, Kimberlé Crenshaw ${ }^{25}$ and Judy Scales-Trent. ${ }^{26}$

Both scholars bring to legal analysis elements of increasingly influential poststructuralist social theory. They combine, in different ways, poststructuralism's emphasis on the multiplicity and intersection of constructing "discourses" and its depiction of a multifocal, decentered self, whose articulation is variable and dependent on context.

23. For interesting theoretical examinations of this claim, see Nancy Fraser \& Linda J. Nicholson, Social Criticism Without Philosophy: An Encounter Between Feminism and Postmodernism, in Feminism/Postmodernism 19 (Linda Nicholson ed., 1990); Kirstie McClure, On the Subject of Rights: Pluralism, Plurality and Political Identity, in Dimensions of Radical Democracy 108 (Chantal Mouffe ed., 1992). Laura Lee Downs and Joan Scott have recently engaged in a dialogue on this subject in the pages of Comparative Studies in Society and History. See Laura Lee Downs, If "Woman" Is Just an Empty Category, Then Why Am I Afraid to Walk Alone at Night? Identity Politics Meets the Postmodern Subject, 35 COMP. Stud. SOCY. \& HIST. 414 (1993) (discussing JoAN W. SCOTt, GENDER AND tHE POLITICS of History (1988)); Joan W. Scott, The Tip of the Volcano, 35 Comp. STud. Socy. \& Hist. 438 (1993) (responding to Downs, supra); Laura Lee Downs, Reply to Joan Scott, 35 Comp. Stud. Socy. \& Hist. 444 (1993).

24. For useful critical assessments of this hypothesis, see ElJzABETH V. SPELMAN, INEssential Woman: Problems of Exclusion in Feminist Thought (1988); Harris, supra note 18 , at $607,612-15$.

25. The works on which I will draw in this discussion are: Kimberle Crenshaw, Whose Story Is It Anyway?: Feminist and Antiracist Appropriations of Anita Hill, in RACE-ING JUsTICE, ENGENDER-ING Power 402 (Toni Morrison ed., 1992) [hereinafter Crenshaw, Whose Story Is It Anyway?]; Crenshaw, supra note 18; Kimberle Crenshaw, Beyond Racism and Misogyny: Black Feminism and 2 Live Crew, Boston Rev., Dec. 1991, at 6 [hereinafter Crenshaw, Beyond Racism and Misogyny]; Kimberlé Crenshaw, Demarginalizing the Intersection of Race and Sex: A Black Feminist Critique of Antidiscrimination Doctrine, Feminist Theory and Antiracist Politics, 1989 U. CHI. LEGAL F. 139 [hereinafter Crenshaw, Demarginalizing the Intersection of Race and Sex].

26. Judy Scales-Trent has written several interesting articles on the intersectionality of race and gender. See, e.g., Judy Scales-Trent, Black Women and the Constitution: Finding Our Place, Asserting Our Rights, 24 Harv. C.R.-C.L. L. Rev. 9 (1989); Judy Trent Ellis, Sexual Harassment and Race: A Legal Analysis of Discrimination, 8 J. LEGIs. 30 (1981) (representing one of the very first articles dealing with complexity in the legal subject under Title VII). But for purposes of the following analysis, I focus on her article, Commonalities: On Being Black and White, Different and the Same, which pursues the distinct theme of categorical ambivalence. Judy Scales-Trent, Commonalities: On Being Black and White, Different and the Same, 2 Y ALE J.L. \& Feminism 305 (1990) [hereinafter Scales-Trent, Commonalities]. 
Crenshaw argues that both feminism and antiracism have failed to account for the distinctive experiences of black women. ${ }^{27}$ Predicated almost exclusively on the experiences or perceptions of white women and black men, these movements have shaped a legal doctrine in which black women do not exist - and a legal system in which they suffer notorious difficulty making their injuries intelligible to decisionmakers. As she describes the legal failure to comprehend the "intersectionality" of race and gender discrimination, Crenshaw also describes a black female subject who is constructed by multiple influences - racism, sexism, and the failure of feminist and antiracist discourses to account for her position. She illuminates this process of construction in her discussion of rape. ${ }^{28}$ Like black men, black women are shaped by the coercive violence of white men; like white women, they often experience it through sexual assault. But unlike either, black women must confront a legal system that for generations has refused their testimony as to matters of sex and still mediates it by reference to a library of particularized stereotypes; they also must face liberatory movements that submerge the distinctive circumstances of black women by focusing on types of victimization characteristic of white women or racebased sexual terrorism targeting black men. ${ }^{29}$ This system of intersecting yet marginalizing influences creates a subjectivity that is multifocal; against the backdrop of the available but always insufficient categories, it seems to be in constant movement. Elaborating on a black feminist response to the Senate "trial" of Anita Hill or to the obscenity prosecution of 2 Live Crew, Crenshaw describes a subjectivity that displays, in different moments, affinities with black men, affinities with white women, and solidarity with the marginalization and the experience of other black women. ${ }^{30}$

Scales-Trent offers a slightly different emphasis. She is concerned not only with the failure of established legal categories to comprehend intersectional experience but also with the failure of any categories to capture the ambivalence and contradiction of

27. This is one of the central theses in Crenshaw's exploration of "intersectionality." Her recent work explores it in a range of contexts. See Crenshaw, Whose Story Is It Anyway?, supra note 25 (rap music and hate speech); Crenshaw, Demarginalizing the Intersection of Race and Sex, supra note 25 (Title VII and antirape politics). 157-60.

28. See Crenshaw, Demarginalizing the Intersection of Race and Sex, supra note 25 , at

29. See id; Crenshaw, Whose Story Is It Anyway?, supra note 25, at 411-16, 419-21.

30. See Crenshaw, Beyond Racism and Misogyny, supra note 25, at 6, 30-33; Crenshaw, Whose Story Is It Anyway?, supra note 25, at 407-21. 
those who apparently reside comfortably within them..$^{31}$ Writing as a person who "[is] black and look[s] white in a society which does not handle anomalies very well,"32 she describes, through narrative prose poetry, the effects this socially created problem of fit has had on her own subjectivity. She must constantly bear the weight of choosing to be either black or white ${ }^{33}$ or confront the sense of dislocation produced when that choice is made for her. ${ }^{34}$ Frequently she feels that she belongs nowhere. ${ }^{35}$ Distinctively revealing as Scales-

31. Scales-Trent, however, is not simply concerned with the incoherence of widely applicable legal and social categories. As indicated by her focus on the emotional pain of living between categories and her choice of a narrative mode of exposition, she is concerned with what living one's life in this unmapped terrain means to and for the many who reside there. In a sense, Scales-Trent's argument partakes of both kinds of questions - questions about categorical incoherence and about its consequences in the lives of people - that Crenshaw identifies in Mapping the Margins. See Crenshaw, supra note 18, at 1297-99 (distinguishing these two types of questions).

32. Scales-Trent, Commonalities, supra note 26, at 305.

33. Scales-Trent writes:

There is so much yet I have to tell you about.

....

... about the guilt of a survivor, always protected by a white-skin disguise.

Is it a disguise?

How am I to take the good things that come my way?

would that cabbie have stopped if he had known?

would the doctor have been civil if ...?

would the clerk have been so helpful?

would the real estate agent have rented me the apartment?

How can I say "no, don't be nice to me; I'm black?"

How can I try to keep from passing when all I'm trying to do is catch a fucking cab? Id. at 309-10.

34. She offers a particularly poignant example:

There she stood in her pink organdy dress,

pink socks,

pink ribbons,

patent leather shoes.

…

She was me when I was six

getting ready for church on Sunday morning -

organdy dress so starched

it scratched,

head tender from the curling iron

Mommie wielded so fiercely:

pressed hair for Jesus, Lord!

....

So I smiled at her,

seeing myself.

And she hid behind her mother's legs

looked up at me

and said

"I'm skeered of white people."

Id. at 315.

35. Scales-Trent writes:

I feel like a fraud. And I hate it. I hate myself for not being able to solve the dilemma.

And I hate black people and white people for putting me out there.

I heap ashes upon my head and beg for forgiveness

Sackcloth and ashes. 
Trent's experience may be, she does not present it as exceptional. On the contrary, she stresses the connections it has helped her forge with other groups that live both in and out of salient categories for example, Native Americans no longer on their tribal reservations $^{36}$ - and with groups that repeatedly shape their identities through conscious, performative choices, including lesbians. ${ }^{37}$ Scales-Trent's invitation to the reader to consider her experiences as having cross-categorical resonance suggests two larger points about the complexity of subjectivity - points that are also made by Crenshaw and other antiessentialist writers.

The first point is that the multifocal quality of subjectivity, and one's movement between different elements of that subjectivity in expressing one's "identity," is not unique to marginalized groups. ${ }^{38}$ The sense of being shaped by multiple, sometimes conflicting practices - exposure to classical music and to gospel - may take on a particular valence in Scales-Trent's case because it is the legacy of an interracial family, but it is not unique to her position as a "white black woman," or even as a black woman. ${ }^{39}$ These contrasting con-

If $I$ am forgiven,

perhaps I will be allowed back into the fold.

Will someone forgive me?

Id. at 310 .

36. See id. at 317-19.

37. See id. at 321-22.

38. This insight means that the unity, or unifocal character, of subjectivity that may appear in particular moments does not reflect a natural unity or a necessary ordering of disparate elements but is, rather, temporary and contingent. Such unity may be achieved, as Angela Harris argues, by an act of will, an assertion of power that temporarily fixes one's identity. See Harris, supra note 18, at 610-15. It may be achieved, as Scales-Trent illustrates, in situations where one's lack of power means that unitary meanings can be conferred by others. See Scales-Trent, Commonalities, supra note 26, at 307 (explaining that she is perceived by "some as white, by some as black, by yet others as a black person but 'really white,' so (a) you can trust her and (b) you can't trust her"). It may be achieved through a moment of temporary affiliation - as when Scales-Trent overcomes her feelings of internal division by affiliation with the lives of her Indian or lesbian "sisters." See id. at 317-19, 321-22. It may be achieved through a moment of opposition - as when she suddenly notices that she may be the only black person in the Kennedy Center. See id. at 308. It may shift in a series of oppositions and affiliations - as when the divorcee whose struggle for legally conferred subsistence, as narrated in Shahbano, identifies alternately as a woman, as a Muslim, as a person with no income. See Zakia Pathak \& Rajeswari Sunder Rajan, "Shahbano," in FEm1. Nists Theorize the Political 257 (Judith Butler \& Joan W. Scott eds., 1992). The contingent character of these affiliations, like their multiplicity within the subjectivity of the persons in question, is not taken by antiessentialist theorists as something anomalous.

39. Scales-Trent makes this point in different ways throughout Commonalities. For example, she argues in one section that part of her feeling of not belonging anywhere and being incompletely understood everywhere was a product of leaving home - "a loss all of us know." Scales-Trent, Commonalities, supra note 26, at 318-19. In another section, she describes the notion of marginality as relative or contextual. She describes an evening in which she and other able-bodied friends were reluctant to leave a restaurant that was only partially accessible to a friend in a wheelchair. In this episode, she continues to describe herself as black, and black-and-white: "Dai was bitter, and angry at us. 'You wouldn't stay here if 
structive influences are a feature of the lives of the privileged as well, as is the resulting sense of having a foot in many camps but not belonging completely or comfortably to any of them. In this sense, the term complex is a misnomer - at least in its implication that there are groups whose subjectivity is simple in comparison. Complexity of the type described by Scales-Trent is a predictable outcome of social construction, particularly in a culture marked by group-based heterogeneity and intersecting systems of oppression. A rich, multiply inflected form of subjectivity prevails across a range of social groups, if observers are prepared to see it. ${ }^{40}$ It is only under the influence of categorical frameworks, such as that of Title VII, or conceptions of a unified self, such as those that have prevailed from the Enlightenment to the early years of identity politics, that such a subject appears complex.

Yet although a range of subjects may be possessed of this kind of complexity, the reluctance of many actors, in both life and law, to depart from more unitary conceptions of subjectivity does not have the same consequences for all of them. This is the second insight, and the one more often stressed by antiessentialist scholars. The striations and tensions, the juxtaposed elements that mark virtually anyone's subjectivity tend to be muted in the lives of more privileged groups. The privilege associated with some characteristics for example, whiteness, maleness, heterosexuality - may permit many people, including those who bear these characteristics, to ig-

there were an entrance for blacks only.' I remember being torn by her analogy." Id. at 323. But she also describes herself as privileged: "[B]ecause $I$ was not in the wheelchair, I was the one who was empowered." Id. So it appears that particularly because the notion of marginality is itself relative and contingent, the kind of categorical ambivalence Scales-Trent describes exists among both the marginal and the privileged. But I also read in Scales-Trent the point I make below - that the categorical ambivalence of the privileged is better accommodated by the social and legal order and may produce less difficulty in their lives.

For another, less stark example of categorical ambivalence in the lives of the privileged and the nonprivileged, see Joe Wood, What I Learned About Jews, N.Y. Times, Apr. 10, 1994, $\S 6$ (Magazine), at 42 (describing two friends, one African American, the other Jewish, each of whom feels as if they contain a little of the other race, by virtue of cultural tastes and exposures).

40. It is with this goal in mind that scholars such as Peggy McIntosh, Elizabeth Spelman, and Martha Mahoney have attempted to highlight contexts that make evident to white women the fact that they have a race as well as a gender. See Peggy McIntosh, White Privilege and Male Privilege: A Personal Account of Coming To See CorresponDENCES Through Work in Women's Studies (Wellesley College Center for Research on Women Working Paper No. 189, 1988); SPELMAN, supra note 24; Martha R. Mahoney, Whiteness and Women, In Practice and Theory: A Reply to Catharine MacKinnon, 5 YALE J.L. \& FEMINISM 217 (1993). Similarly, Maria Lugones has described the resistance of some white women to antiessentialist insights as arising from anxiety about the image of themselves that it projects: an image of fractured unity, of mixed status as victim and perpetrator of discrimination. See Maria C. Lugones, On the Logic of Feminist Pluralism, in FEMINIST ETHICs 35 (Claudia Card ed., 1991). 
nore them, thus reducing the range of influences that are perceived as constructing the subjectivity of group members. ${ }^{41}$ The power of certain groups may also permit them to normalize a particular tension or multiplicity in their members' subjectivities, making them less subject to the anxieties provoked by a perception of complexity. Crenshaw notes, for example, that the intersectional identity of black women has often prompted courts to view them as problematic antidiscrimination plaintiffs, whereas the intersectional identity of white men as affirmative action plaintiffs has posed few barriers to recovery. ${ }^{42}$ The social and legal reliance on unitary conceptions of subjectivity, therefore, does more than apply a simplifying lens to a range of subjects. It imposes a special burden on subjects who lack such indices of privilege - whose constructive or constitutive influences place them at cumulatively greater distance from the groups who prescribe the norm.

\section{The Complex Subject in Title VII Law}

In a growing number of cases, courts have been obliged to confront subjects whose self-characterizations, and consequently whose claims, do not fit readily into the categories prescribed by Title VII. In this Part, I will explore two sorts of tensions between subject and 'statute - tensions that roughly parallel the challenges of complex subjectivity explored by Crenshaw and Scales-Trent. In the first, the construction of the subject by multiple, intersecting influences leads her to manifest a complex identity or subjectivity that the categories of the statute do not reflect. The claimant in these cases faces a difficulty similar to that described by Crenshaw: she argues that she has suffered discrimination not only on the basis of "race" and of "sex" - both categories independently recognized by the statute - but on the basis of "race and sex," an intersectional form of discrimination about which the statute is largely silent.

In the second set of cases, the difficulty is closer to that described by Scales-Trent: the subjectivity of the claimant is not so much intersectional as ambivalent. ${ }^{43}$ The plaintiff claims discrimi-

41. See Spelman, supra note 24. Patricia Cain makes a similar point when she observes that when asked to identify three distinctive characteristics about themselves, white women note gender but not race, though they also have a race, and straight women note gender but not sexual orientation, though they also have a sexual orientation. See Patricia A. Cain, Feminist Jurisprudence: Grounding the Theories, 4 BERKELEY WOMEN's L.J. 191, 208 (19891990). n.12.

42. See Crenshaw, Demarginalizing the Intersection of Race and Sex, supra note 25 , at 142

43. Speaking of this ambivalence in the introduction to her essay, Scales-Trent notes: "In this essay, I struggle to combine two statuses which our society says cannot be combined: 
nation on the basis of race or of gender in the standard, singular manner. Yet the claimant fits uneasily within the category established for statutory protection because she manifests not only characteristics associated with the category but also characteristics associated with the category statutorily presumed to be its opposite: this would be the case, for example, for a black person, like ScalesTrent, who might be viewed as white, or for a man who expresses a "socially female" response to sexualized talk or conduct in the workplace. Moreover, in many of these cases, the perpetrator and the victim of discrimination fall technically within the same statutory category, further complicating the courts' analysis.

In examining these cases, I address two kinds of questions. First, I ask whether courts have been willing to accept the complex subjectivity of these plaintiffs and acknowledge that it renders plausible their unfamiliar claims to relief, or whether courts have been intent on fixing these plaintiffs within a single category and viewing the discrimination they claim as outside the bounds of the statute. Second, when courts have been willing to acknowledge the injury of a plaintiff of this type, I ask whether they have offered an intelligible account of the kind of discrimination such claimants have suffered. I conclude that while the answer to the first question is mixed - courts have sometimes been willing to award relief to such claimants, though more frequently they have not - the answer to the second is almost uniformly negative. The courts offer no account of discrimination against a black woman, or of sexual harassment of a man who exhibits behavior that appears as socially female, that either explains these phenomena on their own terms or helps explain how they relate to the forms of race or gender discrimination traditionally protected under the statute.

\section{A. Discrimination and Intersectionality}

The cases I will examine on intersectionality comprise two types of Title VII action. The first are primarily disparate treatment and occasionally disparate impact actions for termination, failure to hire, or failure to promote; the second are actions for hostile environment sexual harassment.

black cannot be white and white cannot be black." Scales-Trent, Commonalities, supra note 26, at 305. Scales-Trent's personal circumstances present an additional characteristic beyond those at issue in the cases discussed below: her ambivalence is not facially obvious to those who observe her, so she must make constant choices about whether or not to reveal it. This characteristic causes her to feel implicated in the oppression of, or exploitative of the privilege of, one or the other of the groups to which she belongs. 


\section{Hiring, Firing, Promotion}

At first glance, the hiring, firing, and promotion cases involving the assertion of intersectional discrimination - usually on the basis of race and gender - seem to congregate around two poles. ${ }^{44}$ The negative pole is represented by the deservedly notorious DeGraffenreid v. General Motors Assembly Division ${ }^{45}$ In this case the court was asked to determine whether the plaintiffs could maintain a disparate impact challenge to a "last-hired, first-fired" policy on the basis of their status as black women, or whether they would have to challenge the policy on the basis of either race or gender. The plaintiffs had alleged that because of past and ongoing discrimination on the basis of both race and gender, they were uniquely disadvantaged by the defendants' seniority-based policy. 46 The court rejected any notion that "black women are a special class to be protected from discrimination," 47 concluding from the absence of legislative history or applicable precedent that "they should not be allowed to combine statutory remedies to create a new 'superremedy' which would give them relief beyond what the drafters of the relevant statutes intended." 48 ' Then, relying in part on the outcomes of contemporaneous Title VII litigation on the basis of race and of gender, the court concluded that General Motors was not liable for discrimination on the basis of gender and dismissed the case without prejudice so the plaintiffs could join an ongoing action challenging the seniority provisions on the basis of race..$^{49}$

The more promising pole is represented by a later case, Jefferies v. Harris County Community Action Assn. ${ }^{50}$ In Jefferies, a disparate

44. This discussion is informed by a varied and thoughtful body of literature that seeks to examine employment discrimination law from a black feminist perspective. See Regina Austin, Sapphire Bound!, 1989 WIs. L. REv. 539; Crenshaw, Demarginalizing the Intersection of Race and Sex, supra note 25; Ellis, supra note 26; Judith A. Winston, Mirror, Mirror on the Wall: Title VII, Section 1981, and the Intersection of Race and Gender in the Civil Rights Act of 1990, 79 CAL. L. REv. 775 (1991); Cathy Scarborough, Note, Conceptualizing Black Women's Employment Experiences, 98 YALE L.J. 1457 (1989); see also Madeline Morris, Stereotypic Alchemy: Transformative Stereotypes and Antidiscrimination Law, 7 YALE L. \& Poly. Rev. 251 (1989); Jesse B. Semple, Note, Invisible Man: Black and Male Under Title VII, 104 HaRv. L. Rev. 749 (1991).

45. 413 F. Supp. 142 (E.D. Mo. 1976).

46. 413 F. Supp. at 143.

47. 413 F. Supp. at 143.

48. 413 F. Supp. at 143.

49. 413 F. Supp. at 145.

50. 615 F.2d 1025 (5th Cir. 1980).

My discussion of DeGraffenreid and Jefferies reflects the way other commentators characterize this body of law. See, e.g., Morris, supra note 44, at 252 (contrasting the Jefferies approach with the ostensibly outdated DeGraffenreid approach). Crenshaw emphasizes DeGraffenreid as highlighting patterns in Title VII adjudication of black women's claims - 
treatment challenge to the defendants' failure to promote and ultimate termination of the plaintiff, the court acknowledged the possibility of race and gender discrimination that is intersectional, in the sense that it "can exist even in the absence of discrimination against black men or white women." 51 The court considered this ground in addition to the plaintiff's challenges on the bases of race and of sex, despite the fact that the district court had failed to make any findings based on the intersectional claim. The court held that a remedy for "race and sex" discrimination was justified by the language of the statute and its legislative history. "The use of the word 'or' [in setting out statutory categories] evidences Congress' intent to prohibit employment discrimination based on any or all of the listed characteristics," the court declared;52 moreover, the defeat by the House of Representatives of an amendment that would have added the word solely to modify the word sex also suggested that Congress did not intend to leave black women without a remedy against discrimination directed particularly at them. ${ }^{53}$ Perhaps most importantly, the court interpreted the "sex-plus" cases as establishing precedent for protection against intersectional discrimination. ${ }^{54}$ In these cases, courts held that employers cannot enact rules that discriminate against subclasses of women, distinguished not simply by gender but by an additional characteristic such as weight or marital or parental status.55 According to these courts, considering this type of discrimination to elude the "sex" category of the statute

patterns that are further developed in cases involving, inter alia, class representation - but also contrasts it with Jefferies. See Crenshaw, Demarginalizing the Intersection of Race and Sex, supra note 25 , at 143 n.13. Scarborough also emphasizes, as I do, the arbitrary limitations on the "sex-plus" doctrine imposed by Judge v. Marsh, 649 F. Supp. 770 (D.D.C. 1986), although her argument concerns its disparate impact on black women rather than what it reveals about the courts' willingness to accommodate complex subjects. Compare Scarborough, supra note 44 , at 1471-72 with infra notes $61-65$ and accompanying text.

51. 615 F.2d at 1032.

52. 615 F.2d at 1032 .

53. 615 F.2d at 1032.

54. 615 F.2d at 1034. Although Judge Randall authored the Jefferies opinion on behalf of the panel, she indicated in a footnote that she alone of the judges on the panel disagreed with the majority and maintained that the posture of the case did not permit the court to decide whether the plaintiff alleged intersectional discrimination; she also stated that the "sex-plus" cases, which had not involved the use of two statutory categories, did not establish precedent for providing a remedy in cases that did. 615 F.2d at 1034-35 n.7.

55. See, e.g., Phillips v. Martin Marietta Corp., 400 U.S. 542 (1971) (holding that a refusal to hire women with preschool-age children violates Title VII); In re Consolidated Pretrial Proceedings in Airline Cases, 582 F.2d 1142 (7th Cir. 1978) (holding that a policy requiring flight attendants with children to accept ground-duty positions violates Title VII), revd. on other grounds sub nom. Zipes v. Trans World Airlines, 455 U.S. 385 (1982); Sprogis v. United Air Lines, 444 F.2d 1194 (7th Cir. 1971) (holding that a no-marriage rule for stewardesses violates Title VII), cert. denied, 404 U.S. 991 (1971). 
would permit "the rankest sort of discrimination against women."56 It would be illogical, the Jefferies court concluded, if women were protected when the additional factor was a statutorily neutral characteristic but not when the additional factor was also statutorily protected..$^{57}$ Hence the court remanded the case for consideration in terms of "race and sex" discrimination, noting that for purposes of establishing the prima facie case and pretext, "black males and white females ought to be treated as persons outside Jefferies' class."58

This apparently dichotomous judicial approach, however, is not the end of the story. On the one hand, after Jefferies, most courts have been reluctant to follow DeGraffenreid in dismissing intersectional claims out of hand. On the other, Jefferies itself has not proved a durable precedent in securing judicial recognition of intersectional claims. It has been followed in a number of cases, including the much-discussed Chambers v. Omaha Girls Club, ${ }^{59}$ in which the court acknowledged the possibility of a disparate impact action based on discrimination against either black women or single black women ${ }^{60}$ before concluding that defendant's "role model" policy was based on business necessity. Jefferies has also been restrictively construed, however, in ways that shed light on some courts' ambivalence about intersectional discrimination claims.

In Judge v. Marsh, 61 the court concluded that employment decisions directed against black women may violate Title VII but sounded an alarm about the potential scope of Jefferies:

The difficulty with this position is that it turns employment discrimination into a many-headed Hydra, impossible to contain within Title

56. Phillips v. Martin Marietta Corp., 416 F.2d 1257, 1260 (5th Cir. 1969).

57. 615 F.2d at 1034.

58. 615 F.2d at 1034-35.

59. 629 F. Supp. 925 (D. Neb. 1986). This case involved a recently adopted Girls Club rule that required the termination of any staff member who became pregnant outside of marriage. The Club justified this rule on the grounds that unmarried, pregnant staff members were poor role models for young girls in the context of an institution that programmatically sought to persuade them that pregnancies sharply curtailed opportunities for unmarried teenage girls. $629 \mathrm{~F}$. Supp. at 929 . For a thought-provoking discussion of the relationship between this case and the formulation of a black feminist legal theory, see Austin, supra note 44.

60. This court's opinion is somewhat ambiguous on this point. It states that the plaintiff alleged that "black single women" constituted the class affected, but in the next sentence it describes this allegation as reflecting "a combination of racial and sex-based discrimination," omitting any reference to singleness. $629 \mathrm{~F}$. Supp. at 944 . The court's subsequent reference to Jefferies either supports the inference that it is viewing the case as a "race and sex" case or suggests that it views Jefferies as supporting sex-plus cases involving three characteristics. 629 F. Supp. at 944.

61. 649 F. Supp. 770 (D.D.C. 1986). 
VII's prohibition. Following the Jeff[e]ries rationale to its extreme, protected subgroups would exist for every possible combination of race, color, sex, national origin and religion. It is questionable whether any employer could make an employment decision under such a regime without incurring a volley of discrimination charges. For this reason, the Jeff[e]ries analysis is appropriately limited to employment decisions based on one protected, immutable trait or fundamental right, which are directed against individuals sharing a second protected, immutable characteristic. The benefits of Title VII thus will not be splintered beyond use and recognition; nor will they be constricted and unable to reach discrimination based on the existing unlawful criteria. ${ }^{62}$

This ostensibly Solomonic decision is problematic in several respects. Although it appears to follow Jefferies, it departs from that case's statutory construction, which reflects a judgment that discrimination based on any or all of the statutory categories is prohibited by Title VII. More importantly, the court's decision to slay the "many-headed Hydra" and to prevent the emergence of "subgroups for every possible combination" reflects a profound discomfort with the recognition of a complex or multiply constructed subject. By invoking the potential proliferation of categories and imposing the apparently arbitrary restriction on "plus" factors, the Judge decision suggests that Jefferies is an anomaly that must be contained before it reconstitutes antidiscrimination doctrine. The last thing the Judge court claimed to see in Jefferies was an invitation to reconsider the way that discrimination operates on or across groups, or the way that groups come to be constructed by discriminatory practices.

Some responsibility for this retreat, however, must fall on the Jefferies court, for that opinion offers scant elaboration of the innovation it effects. Although it states that discrimination against particular subgroups of women should be viewed as statutorily pernicious ${ }^{63}$ and that black women may suffer discrimination when black men and white women suffer none, ${ }^{64}$ Jefferies provides little substantive description of the discrimination it seeks to prevent. It never answers several questions that are crucial to explaining the nature of intersectional discrimination. First, should the discrimination against black women be regarded as distinct because it is quantitatively greater - as they suffer a combination of what black men and white women receive - or because it is qualitatively different?

62. 649 F. Supp. at 780 (citation omitted).

63. 615 F.2d at 1034.

64. 615 F.2d at $1032,1034$. 
Second, if this difference is qualitative, is the discrimination suffered by black women utterly distinct, or can it be related, even in its particularity, to the discrimination suffered by other groups of women? The Judge court's description of a "many-headed Hydra"65 suggests that the claims of each subgroup are highly particularized and lack common threads with the race or gender discrimination suffered by other subgroups; the Jefferies opinion offers little ground for assessing this suggestion. Finally, how should one describe the relationship between this intersectional form of discrimination and those previously addressed under the statute? Are those forms of discrimination that target a subgroup less important - as Judge's imposition of arbitrary limits suggests - than those that target the group as a whole? Are those forms of discrimination frequently regarded as general really as universal as they seem, or do they simply target a subgroup - white women which is not often recognized as a subgroup? ${ }^{66}$ None of these questions received attention from the Jefferies court. Jefferies may have opened the door to the protection of a particular intersectional category, but because it fails to describe the conception of intersectional discrimination that animates this protection or how that conception relates to more traditional understandings of discrimination under Title VII, the protection it offers is neither transformative nor, ultimately, even stable.

\section{Sexual Harassment Cases}

The sexual harassment cases reflect different kinds of postures from claimants and different - though equally ambivalent - responses from courts. Although many sexual harassment cases involve black women plaintiffs, plaintiffs comparatively rarely plead their cases as "race and sex" cases, even when the allegations appear to support an intersectional interpretation. When plaintiffs have interjected intersectional elements, those issues frequently emerge with respect to evidentiary issues or on appeal. An example of the first pattern is Brooms v. Regal Tube Co. ${ }^{67}$ Brooms in-

65. 649 F. Supp. at 780 .

66. We may be unaccustomed to thinking about whiteness as race, particularly in the context of antidiscrimination analysis, because it confers a race privilege rather than a race disadvantage. See supra notes 40-41. If one comes to be located within a subgroup of the group women by virtue of having a race, however, then white women are a subgroup as well. Moreover, the treatment conferred on white women can be understood as intersectional in that it responds to - and helps to create - gender disadvantage and race privilege.

67. 881 F.2d 412 (7th Cir. 1989), overruled in part by Saxton v. American Tel. \& Tel. Co., 10 F.3d 526 (1993). Another example of a sexual harassment case with largely undiscussed racial overtones is Jew v. University of Iowa, 749 F. Supp. 946 (S.D. Iowa 1990). Jean Jew, a 
volved a pattern of repeated harassment by a supervisor beginning with (rejected) propositions, continuing with the plaintiff's compelled exposure to "racist pornograph[y]" 68 accompanied by racial slurs, ${ }^{69}$ and culminating in physical injury to the plaintiff when the supervisor threatened her life and she fell down a flight of stairs attempting to escape. Brooms sued under section $1981^{70}$ for racial harassment and under Title VII for sexual harassment and retaliatory discrimination. After losing a jury verdict on the section 1981 claim, she prevailed on her Title VII claim for sexual harassment. Several factors contributed to the submersion of the intersectional character of the harassment in this case. The first was the plaintiff's pleading of the case: the complaint bifurcated the race and gender claims by statute as well as by claim, and there was no "race and gender" claim. The intersectionality of the plaintiff's claim was also submerged by the court, which noted the "racist" nature of the pornography and the attendant derogation but offered nothing about the implications of these facts for the nature of the plaintiff's claim. Although there were plausible reasons for these choices - the plaintiff may have viewed the sexual harassment claim as so strong on its facts that there was little to be gained by complicating it with a comparatively unfamiliar legal theory, and the court may have been reluctant to exceed the bounds of plaintiff's legal claims they ultimately had costs for the plaintiff. Brooms lost her racial harassment claim, and with it her opportunity for punitive damages. ${ }^{71}$ Although it is difficult to look behind a jury verdict, it is possible that the failure of the plaintiff to stress the racial inflection of the sexual harassment and the failure of preexisting doctrine -

Chinese-American professor of anatomy, was subjected to an intense campaign of sexist slurs by colleagues and denigrating graffiti in faculty buildings because of her professional association with an unpopular department chair. These slurs included such terms as chink and Chinese pussy. See Martha Chamallas, Jean Jew's Case: Resisting Sexual Harassment in the Academy, 6 YALE J.L. \& Feminism 71, 74 (1994) (citing 749 F. Supp. at 949 and Plaintiff's Memorandum in Opposition to Defendant's Motion for Summary Judgment at 10, Jew v. University of Iowa, 749 F. Supp. 946 (S.D. Iowa 1990) (No. 86-169-D-2)). Although Jew ultimately prevailed in her sexual harassment claim, neither her framing of the case nor the court's decision called attention to the racial strain in the harassment. For a thoughtful analysis of Jew's long struggle for legal vindication and its implications for current cultural understandings regarding sexual harassment, see Chamallas, supra.

68. 881 F.2d at 417 . As described by the court, some of this material depicted interracial sex in a manner that may have suggested the subordination of the black woman, and some of the material associated black women with bestiality. See 881 F.2d at 417 .

69. Gustafson, the supervisor, allegedly stated that a picture showing a woman engaged in an act of sodomy showed the "talent" of a black woman. 881 F.2d at 417.

70. Act of Apr. 9, 1866, ch. 31, § 1, 14 Stat. 27 (codified as amended at 42 U.S.C. $\S 1981$ (1988)).

71. See 881 F.2d at 417. 
as replicated by this court - to legitimate the intersectional category limited the extent to which the evidence in this case could be used to support a finding of racial harassment.

In other cases, however, black women plaintiffs have placed more emphasis on the intersectional character of their claims. In Hicks v. Gates Rubber Co., ${ }^{72}$ the plaintiff initially sued for racial harassment under section 1981 and for racial and sexual harassment under Title VII. The harassment at issue included a variety of racial epithets, some targeted at the plaintiff and at least one particularly evocative of discrimination against black women, ${ }^{73}$ as well as sexual comments toward and sexual touching of the plaintiff by her supervisor. The plaintiff lost on all claims at the trial court level. When she appealed, alleging, inter alia, an erroneous failure by the district court to consider hostile environment sexual harassment, she sought to combine the evidence of racial hostility - itself found insufficient to support a racial harassment claim - with the evidence of sexual harassment "to prove a pervasive pattern of discriminatory harassment."74 The court of appeals acceded to her demand, citing Jefferies's construction of Title VII, as well as its "sex-plus" rationale for allowing a "race and sex" claim.75 It stated that black female plaintiffs in such cases should be able to "aggregate evidence of racial hostility with evidence of sexual hostility."76

Hicks, however, like Jefferies, has been uncertain in its precedential effects. Two recent cases, Stingley v. Arizona ${ }^{77}$ and Clay v. $B P S$ Guard Services, ${ }^{78}$ illustrate the range of judicial response. In Stingley, the court not only followed Hicks in permitting aggregation of racial and sexual evidence 79 but insisted that the standpoint from which to evaluate allegations be particularized to include both race and gender in cases in which the plaintiff is a black woman. ${ }^{80}$ In Clay, on the other hand, the court resisted the intersectionality of the plaintiff's claim. Clay sought relief under Title VII for sexual and racial harassment culminating in constructive discharge. She had been exposed to physical assault on account of race, as well as

72. 833 F.2d 1406 (10th Cir. 1987).

73. The plaintiff alleged that one of her co-workers had referred to her as "Buffalo Butt." 833 F.2d at 1409.

74. See 833 F.2d at 1415.

75. 833 F.2d at 1416.

76. 833 F.2d at 1416.

77. 796 F. Supp. 424 (D. Ariz. 1992).

78. No. 92 C 2127, 1993 U.S. Dist. LEXIS 8399 (N.D. Ill. June 18, 1993).

79. See 796 F. Supp. at 428.

80. See 796 F. Supp. at $428-29$. 
to a steady stream of verbal abuse, including repeated designation as the "nigger bitch," derogatory references to her sexual preference, and descriptions of people of her race as "those who liked to live off welfare because they are lazy." 81 The defendant moved to strike those portions of the plaintiff's complaint that related to sexual harassment on the ground that her EEOC complaint, and the ensuing investigation, had raised allegations relating only to race. ${ }^{82}$ The court granted the motion, stating that claims of discrimination outside the original EEOC charge were cognizable only to the extent that they are " "like or reasonably related to the allegations of the charge and growing out of such allegations.' "83 It declined to credit the possibility that epithets like nigger bitch or references to lazy people on welfare implied derogation on the basis of sex as well as of race.

The sexual harassment doctrine, like that relating to hiring, firing, and promotion, reflects some steps toward the recognition of complex claimants. The acknowledgment in Hicks and Stingley that black women may be differently situated than white women with respect to proving a sexual harassment claim reflects a recognition that even as women - that is, those who are claiming sexual harassment - claimants are constructed by race as well as gender. But the incomplete and flawed elaboration of that understanding by the courts has created difficulties. The emphasis on aggregation of evidence has raised an inference - operating as a limit, even though it is never explicitly defended - that discrimination against black women should be viewed primarily as an additive phenomenon. Moreover, in failing to discuss particular epithets and the kinds of discriminatory understandings they convey, courts have forgone an important opportunity to show an intersectional dynamic at work. Terms like nigger bitch or Buffalo Butt are unlikely ever to be used against either black men or white women; they convey a kind of racialized sexual hostility, or sexualized racial hostility, that cannot be disaggregated into its component parts. The failure to discuss the nature of the discriminatory animus at work in such examples has meant that triers of fact cannot see the racial element in what has been styled as sex discrimination - as in Brooms - or the sexual element in what has been styled as race discrimination - as in Clay. This failure has shaped unnecessary

81. 1993 U.S. Dist. LEXIS 8399, at *3.

82. 1993 U.S. Dist. LEXIS 8399, at *6.

83. 1993 U.S. Dist. LEXIS 8399, at *9 (quoting Perera v. Flexonics, Inc., 727 F. Supp. 406, 412-13 (N.D. Ill. 1989)). 
losses for black women plaintiffs, as well as a reluctance on the part of many claimants to plead "race and sex" harassment. ${ }^{84}$

Thus, although some courts have felt compelled to acknowledge the intersectional position of black women by allowing a "race and sex" claim under Title VII, they have not consolidated that protection by providing an account of the discrimination that this group faces. They may invoke, though not explain, an aggregative understanding of "race and gender" discrimination. Even this partial description comes at a price: it requires plaintiffs to separate evidence into "race" and "gender" categories and select a primary focus in presenting their case. Moreover, the failure to explain how intersectional discrimination in these cases relates to more conventional understandings of discrimination can make the claims of black women seem narrow or partial, while the claims of white women who also occupy an intersectional position - appear inclusive or universal. ${ }^{85}$ Finally, the courts' view of intersectionality in these cases as an anomaly, rather than as a way of reconceiving the subjectivity of any claimant, leads them to cabin rather than to investigate its influence.

\section{B. Discrimination and Categorical Ambivalence}

The claimants featured in the second set of cases manifest a different kind of complex subjectivity: it is produced, not by the intersection of two categorical traits, but by the juxtaposition of qualities thought to occupy polar positions within the same categorical dichotomy. Plaintiffs may be blacks with light skin, men who behave in "socially female" ways, women who respond to sexual harassment in a manner more typical of men. ${ }^{86}$ The ways in which courts

84. It is interesting to note that academic arguments about confluence predate most or all of these cases. See, e.g., Ellis, supra note 26. In the face of judicial refusal to elaborate the intersectionality in particular instances of abuse, however, it is not altogether surprising that plaintiffs and their attorneys have proved reluctant to press such claims.

85. See Crenshaw, Demarginalizing the Intersection of Race and Sex, supra note 25 , at 143-46 (discussing Moore v. Hughes Helicopter, Inc., 708 F.2d 475 (9th Cir. 1983), as an example of one consequence of this contrast: white women can represent a class composed of all women employees of a particular employer, but black women cannot).

86. It is possible to argue that lesbians and gay men are categorically ambivalent with respect to the category gender. It is certainly true, as Sylvia Law and Marc Fajer have argued, that the choice of a sexual partner of the same sex, as well as certain consciously assumed behavioral characteristics of some lesbians and gay men, place them outside the complex of social norms and expectations associated with biological maleness or femaleness. See Marc A. Fajer, Can Two Real Men Eat Quiche Together? Storytelling, Gender-Role Stereotypes and Legal Protection for Lesbians and Gay Men, 46 U. MIAM1 L. REv. 511, 617-33 (1992); Sylvia A. Law, Homosexuality and the Social Meaning of Gender, 1988 WIs. L. REv. 187, 218-21.

I am ultimately reluctant, however, to describe lesbians and gay men as categorically ambivalent with respect to gender, because $I$ am concerned that such a definition would assimi- 
respond to such claimants are not dissimilar from those described above. Courts do not consistently deny relief to such claimants, so plaintiffs have been victorious even in cases in which the perpetrators of their discrimination come from the same statutory categories. Yet courts often fail to acknowledge such complex claimants as the victims of discrimination, and the persuasiveness and stability of even positive outcomes has been undermined by a failure to elaborate the discrimination that such cases reflect. ${ }^{87}$

late sexuality to gender, or instantiate an understanding of gender as connoting heterosexuality. Katherine Franke, for example, observes that a small but revealing body of opinions in which the law has been called upon to resolve cases involving ambivalence as to sex have pointed to (i) biological endowments and (ii) the sex of the object of the claimant's desire as the indices most important in establishing the claimant's sex for legal purposes. See Katherine Franke, Cherchez La Femme: Law, Sexual Identity and Desire 43 (1994) (unpublished manuscript, on file with author) (discussing cases in which the law was required to establish the sex of the claimant, including matrimonial cases involving transsexuals, violations of sumptuary laws, and so on). This has had the effect of rendering lesbians not quite fully female and gay men not quite fully male in the eyes of the law. Id. Particularly in light of this danger, I would prefer to follow the lead of a sizeable and interesting literature, beginning with the literature of the "sex wars" of the early 1980 s and continuing with the emerging field of Queer Theory, that emphasizes the complexity of the relationship between gender and sexuality. See, e.g., Judith Butler, Bodies that MATter (1993); Judith ButLer, Gender Trouble (1990); Eve K. Sedgwick, Epistemology of the Closet (1990); see also Gayle Rubin, Thinking Sex: Notes for a Radical Theory of the Politics of Sexuality, in Pleasure and Danger: Exploring Female Sexuality, supra note 20, at 267. Sexuality, in general, and its relation to gender, in particular, seem to me too complex to permit the assimilation of homosexual sexual orientation to categories such as socially male or socially female.

87. In the cases I discuss below, the categorical ambivalence with respect to race is frequently a function of biology - that is, the claimant has a mixed race background and consequently manifests lighter skin - whereas the categorical ambivalence with respect to gender is a function of the interplay between biological sex and social characteristics - that is, the claimant manifests social characteristics that do not correspond to his or her biological sex. My emphasis on cases that display this configuration should not be taken to suggest, however, that categorical ambivalence with respect to race need be biological or categorical ambivalence with respect to gender need be a product of the interaction of biological and social traits. In fact, it is not difficult to identify cases in which precisely the opposite patterns prevail. One of the great contributions of Kimberle Crenshaw's essay on the Clarence Thomas-Anita Hill hearings is to point out that both Clarence Thomas and Anita Hill were categoricaily ambivalent with respect to race over the course of the hearings. See Crenshaw, Whose Story Is It Anyway?, supra note 25. This ambivalence arose from the interaction of their biological race with the - often changing - social constructions that were applied to them and their actions during the course of the hearings. Anita Hill, biologically a black woman, was deraced - that is, rendered white in the minds of senators and the national television audience - by the fact that her actions with respect to Thomas were explained by reference to narratives patterned on the experience of white women and by Thomas's appropriation of the mantle of race with his "high tech lynching" speech. Id. at 407-16. Thomas, biologically a black male, was constructed as black by his selection to fill the vacancy left by Thurgood Marshall, reconstructed as nonblack by his insistently color-blind characterization of his life and commitments during the first stage of the hearings, and reconstructed as black by his use of the metaphor of the "high tech lynching" to defend himself against the charges of Anita Hill. Id. at 407-21. I thank Anna Marie Smith for helping me to see this point. Conversely, there are a number of gender cases involving transsexuals in which categorical ambivalence with respect to gender is a function of ambivalence in biology. See, e.g., B. v. B., 355 N.Y.S.2d 712 (Sup. Ct. 1974) (involving an annulment sought on grounds that the husband, a postoperative transsexual who had been born a woman, had fraudulently concealed 


\section{Hiring, Firing, Promotion}

The mid-1980s saw the rise of race discrimination claims filed by plaintiffs who were technically within the same racial category as the defendants they accused. In the context of 42 U.S.C. $\$ 1981$, these cases were most often claims between whites of different ethnic groups; the two most prominent cases dealt with a Jew suing non-Jewish whites ${ }^{88}$ and an Arab suing non-Arab whites ${ }^{89}-$ although one later case involved an action between two Puerto Ricans. ${ }^{90}$ In the later-emerging context of Title VII, blacks filed suits against other blacks. A look at two leading cases of this type, Walker v. Internal Revenue Service ${ }^{91}$ and Hansborough v. City of Elkhart Parks and Recreation Department, ${ }^{92}$ reveals the analytic knots in which courts have tied themselves, seeking to respond to the complexity they present.

Walker was a suit by a light-skinned black woman, alleging discrimination perpetrated by a dark-skinned black woman. After a "strained" relationship in which the plaintiff was frequently singled out for criticism regarding insubstantial or imagined faults, she was fired by her supervisor for tardiness, incompetence, and attitude problems. ${ }^{93}$ She alleged that her termination was attributable to her supervisor's bias against light-skinned black people. ${ }^{94}$ The court rejected a magistrate's recommendation that the defendant be granted summary judgment because a Title VII action was not available to a light-skinned black person claiming discrimination by a dark-skinned black person. ${ }^{95}$

The court accepted the plaintiff's characterization of the case as discrimination on the basis of "color," rather than race. It relied first on statutory interpretation to conclude that it was appropriate to treat race and color as distinct, ${ }^{96}$ and then on a series of section 1981 cases that appeared to support the court's recourse to color by

his "true sex"); City of Columbus v. Zanders, Nos. 74AP-88, 74AP-90, 74AP-92, 74AP-93 (Ohio Ct. App. Oct. 22, 1974) (LEXIS, States library, Ohio file) (upholding the convictions of a preoperative transsexual for two violations of sumptuary laws). For an interesting discussion of these and other cases of biological gender ambivalence, see Franke, supra note 86.

88. See Shaare Tefila Congregation v. Cobb, 481 U.S. 615 (1987).

89. See Saint Francis College v. Al-Khazraji, 481 U.S. 604 (1987).

90. See Franceschi v. Hyatt Corp., 782 F. Supp. 712 (D.P.R. 1992).

91. 713 F. Supp. 403 (N.D. Ga. 1989).

92. 802 F. Supp. 199 (N.D. Ind. 1992).

93. 713 F. Supp. at 404.

94. 713 F. Supp. at 404-05.

95. 713 F. Supp. at 408.

96. 713 F. Supp. at 405-06. 
permitting actions between people who were technically of the same race but differed in "ancestry or ethnic characteristics."97 In particular, the court rested on a Supreme Court case, adjudicated under section 1981, that had permitted race discrimination claims among different subgroups of whites because plaintiffs and defendants were distinguished by their divergent ethnic backgrounds. ${ }^{98}$ In Saint Francis College v. Al-Khazraji, the Court held that the meaning of race in the statute should not be limited by contemporary understandings highlighting three major racial groups; instead, it should be read by reference to its nineteenth-century context, in which race encompasses ethnic divisions, or denotes, in broader terms, the "stock" from which one is descended.99 The embodiment of this understanding in section 1981's legislative history 100 made it clear that nineteenth-century legislators would have understood Arab Americans and Anglo-Saxon Americans as belonging to different racial groups, notwithstanding the fact that both might be described as Caucasian. Citing to Al-Khazraji, the Walker court observed that "[i]t would take an ethnocentric and naive world view to suggest that we can divide caucasians into many sub-groups but some how all blacks are part of the same sub-group."101 It then concluded that the fact that the plaintiff and the defendant were both black did not, as a matter of law, prevent the plaintiff from suing under Title VII: whether the plaintiff's allegations are justified, despite the fact that the defendant belongs to the same race, is a question of fact that must be determined by the fact finder. ${ }^{102}$

In Hansborough v. City of Elkhart Parks \& Recreation Department, ${ }^{103}$ which concerned a claim of discriminatory termination, ${ }^{104}$

97. 713 F. Supp. at 406 (citing Saint Francis College v. Al-Khazraji, 481 U.S. 604, 613 (1987)).

98. Although the court used Al-Khazraji to support its recourse to color in the sense that this cases concerned the statutory viability of claims between members of the same race, $A l-$ Khazraji did not place intraracial cases within a separate category but rather took a broader view of the term race. Thus, strictly speaking, the categorical logic of Al-Khazraji is more supportive of the court's approach in Hansborough than in Walker. See infra notes 104-18 and accompanying text.

99. 481 U.S. at $610-13$.

100. As the Court noted, the statute's legislative history indicates "that Congress intended to protect identifiable classes of persons who are subjected to intentional discrimination solely because of their ancestry or ethnic characteristics." 481 U.S. at 613.

101. 713 F. Supp. at 407-08.

102. 713 F. Supp. at 408.

103. 802 F. Supp. 199 (N.D. Ind. 1992).

104. There is no indication in the opinion that Hansborough was of a different skin tone than his supervisor. Thus, one might legitimately wonder why I have classified Hansborough as a case of categorical ambivalence for purposes of this discussion. In so doing, I am seeking to interpret Hansborough's allegation that his supervisor discriminated against him on the 
the court framed the question, not in terms of color, but in terms of race. ${ }^{105}$ The court ruled out reliance on legislative history, stating that this "specie of discrimination was not even a minor consideration in the eyes of the sponsors of the legislation."106 The court then followed Walker in relying on the section 1981 cases, but it interpreted $A l$-Khazraji and Shaare Tefila, not as supporting the use of the category color, but as placing intraracial discrimination within the category race. ${ }^{107}$ It endorsed the Al-Khazraji Court's discussion of the arbitrariness inherent in racial classification ${ }^{108}$ and concluded, with Walker, that if intraracial discrimination is possible among whites, it must also be possible among blacks. ${ }^{109}$ Relying apparently on the atypicality of the claimed discrimination, however - among the interactions of people of the same race, or among the concerns of Title VII's framers - the court held that a

basis of race. Thus, assuming that race was actually an issue, it was because the supervisor perceived some difference between the race she manifested - the supervisor was a woman - and the race Hansborough manifested. Because the case provides no indication that either Hansborough or his supervisor had a mixed-race heritage, this perception of difference would seem likely to stem from social-role expectations regarding blackness. In treating the case as an analog to Walker - as concerning a categorically ambivalent claimant - I am assuming that the supervisor viewed Hansborough as biologically black and socially white, or not black, while viewing herself as both biologically and socially black, and discriminated against him on that basis. Because Hansborough alleged both race and sex discrimination an aspect of the claim that was, interestingly, not explored because of the ostensibly preliminary need to address the intraracial aspect of the claim - it also appears that the supervisor discriminated against Hansborough because of his failure to conform to social-role expectations for his biological category black male. Either of these explanations would make the case analogous to Walker in presenting a categorically ambivalent black claimant, but even more analogous to the sexual harassment cases, see infra section II.B.2, in that the claimant's ambivalence is a function of the interaction of biology and social role expectation.

If the supervisor, however, as a black woman, sanctioned Hansborough for his failure to conform to social role expectations connected with black men, this would not, technically speaking, be a case of discrimination among persons who occupied the same category.

It is also possible that the supervisor discriminated against Hansborough because she viewed herself as biologically black but not socially black - or socially black female - and Hansborough as biologically and socially black (male). If this were the case, Hansborough would still be interesting as a case about categorical ambivalence, as it considers antiblack race discrimination perpetrated by a person who was biologically black yet did not think of herself as black, but it would not, technically speaking, be a case about a categorically ambivalent claimant.

105. It is not clear from the opinion, but it is possible that a claim based on color was not available to Hansborough because he was not of a different skin tone than his supervisor.

106. 802 F. Supp. at 203.

107. See 802 F. Supp. at 203-06.

108. See 802 F. Supp. at 205 (" "There is a common popular understanding that there are three major human races .... . Many modern biologists and anthropologists, however, criticize racial classifications as arbitrary and of little use in understanding the variability of human beings." " (quoting Al-Khazraji, 481 U.S. at 610 n.4)). The foregoing quote suggests the ultimate indeterminacy and varying social construction of categories such as race; this view, however, is neither the norm in Title VII cases, see infra section III.A, nor fully embraced in Walker or Hansborough, which decline to explore intragroup constructions of race.

109. See 802 F. Supp. at 206. 
plaintiff who alleges intraracial discrimination bears a "relatively unique and difficult burden of proof." 110 Hansborough, who offered no such evidence regarding the employer in general or his supervisor in particular, failed to carry this burden.

These cases resolve the categorical questions presented without confronting the kind of discrimination involved. This is particularly true in Walker, which uses the category color to step around the question. Reliance on color is not irrational in a case where the distinction between the two black parties is one of skin tone, or color. The court's insistence, however, on treating color as a category distinct from, and unshaped by the incidents of, race ${ }^{111}$ is more problematic. It suggests that the court may be less interested in clarifying its understanding than in evading the paradoxical racial relationship between the parties. Differences in color may be relevant to blacks in an aesthetic sense that has little to do with interracial discrimination. "[W]e black people have always had a delicious way of describing ourselves,"112 notes Shirlee Taylor Haslip in a recent memoir. "We call ourselves honey, caramel, ivory, peachesand-cream, mahogany, coal blue, red, bronze, amber ...."113 Yet when differences in color become a source of antagonism between blacks, the reasons cannot be so easily separated from race. In this society, whites have made Caucasian race - and, by inference, fair skin - a source of privilege. That blacks may internalize these meanings and apply them against other blacks seems paradoxical but is sometimes true: this pattern was, in fact, the subject of expert testimony when Walker returned for fact-finding. ${ }^{114}$ Yet it is an issue that the court avoids raising or delineating when it acknowl-

110. 802 F. Supp. at 207.

111. The court is not completely consistent about this: at times it seems not so much insistent on separating race and color as it is unclear about the relation between them. It quotes Felix v. Marquez, 24 Empl. Prac. Dec. (CCH) I 31, 279 (D.D.C. 1980), to the effect that " "color is usually mixed with or subordinated to claims of race discrimination, but considering the mixture of races and ancestral national origins in Puerto Rico, color may be the most practical claim to present." $713 \mathrm{~F}$. Supp. at 406 (quoting Felix, 24 Empl. Prac. Dec. at $31,279)$ (emphasis added by the Walker court). The Walker court notes that "[d]iscrimination against an individual because such individual comes from a racially mixed heritage possibly is of particular relevance to the instant case." 713 F. Supp. at 406-07. But the Felix case is treated as exceptional, discussed largely because the defendant - erroneously, in the court's view - raised it in support of his case. Most of the court's analysis is built on the analogy between differences in color and among ethnicities in the $\$ 1981$ cases.

112. Shirlee T. Haslip, The Sweeter the Juice 30 (1994).

113. $I d$.

114. Two expert witnesses reporting on intraracial perceptions of skin tone within the black community noted that "some darker-skinned blacks may have a feeling of inferiority in dealing with lighter-skinned blacks which may sometimes result in hostile or prejudicial treatment of the latter by the former." Walker v. IRS, 742 F. Supp. 670,675 (N.D. Ga. 1990) (Walker II), affd. without op., 953 F.2d 650 (11th Cir.), cert. denied, 113 S. Ct. 156 (1992). 
edges the availability of an intraracial claim. The court's attempt to steer clear of these turbulent waters ${ }^{115}$ by resurrecting and isolating the quiescent statutory category of color seems peculiar and strained.

Although Hansborough resolves to decide the question on the basis of race, it too reaches an odd explanatory impasse through its reliance on $A l-K h a z r a j i$. The problem, of course, is not the analogy between section 1981 and Title VII but the implied analogy between the racial subgroups in question. The court's assurance that " '[i]t would take an ethnocentric and naive world view to suggest that we can divide caucasians into many sub-groups but some how all blacks are part of the same sub-group" "116 belies the fact that it is unwilling to perform for blacks the detailed intragroup analysis it provides for whites. Both decisions suggest that the problem highlighted by the section 1981 cases is one of shifting antagonisms between ethnic subpopulations of the same racial group. The Walker court completes the analogy, citing the "sharp and distinctive contrasts amongst native black African peoples (sub-Saharan) both in color and in physical characteristics."117 But Walker is not a case between blacks who trace their lineages to different African subcul-

Notwithstanding this evidence, the court in Walker II held that the plaintiff failed to prove by a preponderance of the evidence that her termination was the result of invidious discrimination, and the defendant offered legitimate, nonpretextual reasons for the termination. 742 F. Supp. at 676. The court concluded that there were non-color-based interpersonal conflicts between the plaintiff and her supervisor and that there was evidence suggesting that the plaintiff was "insubordinate, immature, impatient, disrespectful and unmanageable." $742 \mathrm{~F}$. Supp. at 676. One difficulty in the plaintiff's case seemed to revolve around the fact that any comments made by her supervisor that seemed to denote intraracial prejudice - for example, "[Y]ou need some sun" - were made behind closed doors without other witnesses. 742 F. Supp. at 675 \& n.4.

Another possible explanation for intragroup discrimination is the so-called gatekeeper function. Members of protected groups understand at some level that their institution is unlikely to tolerate more than token representation of their group; as a result, they may police the entry of more members of that group into the institution in order to protect their own position. See Letter from Martha Chamallas, Professor of Law, University of Iowa, to Kathryn Abrams, Professor of Law, Cornell University (July 15, 1994) (on file with author) (describing explanations by African-American students of intragroup discrimination). Catharine MacKinnon has cited this pattern as a reason that some women oppose feminism, particularly feminist efforts to regulate pornography. See MACKinnon, On Collaboration, in FEMINISM UNMODIFIED, supra note 8, at 198, 205.

115. The court's very rendition of the facts of the case seems to point in the direction of this issue: "Ms. Walker has not presented any direct evidence that Ms. Lewis was prejudiced against light-colored skinned blacks. There is evidence that Ms. Lewis might have harbored resentful feelings toward white people, and therefore by inference, possibly toward lightskinned black people." 713 F. Supp. at 404-05. Yet, having related these facts, the court never returned in any substantive way to discuss the discriminatory pattern they suggest.

116. 802 F. Supp. at 206 (quoting 713 F. Supp. at 407-08).

117. 713 F. Supp. at 408. 
tures; ${ }^{118}$ Hansborough describes no apparent differences between the plaintiff and the alleged perpetrators. The subgroup differences, categorical ambivalences, and displaced antagonisms that might fuel discrimination among blacks are never framed or discussed.

It is possible to interpret Al-Khazraji and Shaare Tefila in another way: not simply as highlighting ethnic antagonisms, but as highlighting ethnic antagonisms that are structured within, and take some of their meaning from, the dynamics of race. Jews and Arabs might represent groups whose members appear to be Caucasian but are not socially understood as white. If these cases reflect ScalesTrent's insight that the great racial divide does not exhaust the American social appetite for hierarchy and subordination - that there are blacks within whites, and whites within blacks, social constructs that have little to do with biological difference - $\mathrm{Al}$ Khazraji and Shaare Tefila might be used to give substance to the intragroup discrimination acknowledged in Walker and Hansborough. Yet it is not obvious that the Court intended them to be read in this way; ${ }^{119}$ more importantly, the Title VII cases do not even try to do so. ${ }^{120}$ They prefer to permit the same-race claims, while leaving unelaborated the notions of intragroup discrimination that might give them content.

118. A brief suggestion that it involves a dispute between southern and northern blacks is never pursued. See Walker II, 742 F. Supp. at 675.

119. The strongest suggestion that these cases might be interpreted in this way comes from Shaare Tefila. In that case, the Court reversed a court of appeals decision stating that Jews may not avail themselves of the protection of 42 U.S.C. $\S 1982$ (1988) on the ground that " 'discrimination against Jews is not racial discrimination." 481 U.S. at 617 (quoting Shaare Tefila Congregation v. Cobb, 785 F.2d 523, 527 (4th Cir. 1986)). The Court's conclusion that discrimination against Jews may be racial discrimination, despite the fact that Jews are technically Caucasians, might mean that if a plaintiff is outside a biologicaily based category but is the recipient of the same kind of animus that is directed against those in the category - that is, if the plaintiff is assimilated, by social construction, to those within the category - a claim of discrimination will lie. The Court also held, however, that the defendant's animus itself is not sufficient to create a claim under $\S 1982$ and that the plaintiff must belong to a group that the statute was intended to protect, a condition that Jews, under $\mathrm{Al}$ Khazraji's broad interpretation of race, satisfy. 481 U.S. at 617 . Because of the second requirement, the case may be more plausibly interpreted as meaning that the Court believed it had to find both membership in an ethnic group of the type covered by the statute and animus against that group - "race" in the broad sense - in order to extend protection under $\S 1982$.

120. Similarly, one might wonder about Hansborough's holding that the plaintiff in an intraracial case must bear a "unique and difficult burden of proof." $802 \mathrm{~F}$. Supp. at 207. If it is simply a reflection of social probabilities - that whites are more likely than blacks to act on the basis of bias against blacks - it seems reasonable enough. Yet to the extent that it may be understood as an effort to exceptionalize racialized thinking within racial group boundaries, it may be less innocuous. 


\section{Sexual Harassment}

The sexual harassment cases present a similar difficulty in the context of gender: the possibility that one can both be and not be a member of a protected group - the possibility that one can suffer group-based discrimination perpetrated by a member of the group in question. In the sexual harassment cases, the social constructedness - and ultimate instability - of the statutory categories is even clearer: what causes the plaintiff to fit uneasily within the established category is not a physical characteristic, such as skin color, but the plaintiff's own behavior. In the most striking of these cases, the plaintiffs are men who fit awkwardly within their ostensible gender category because of their discomfort with sexualized talk and conduct in the workplace. ${ }^{121}$

121. In a second set of cases, the plaintiffs are women who fit uneasily within their category because of their response to the experience of being harassed. These cases are not precisely analogous to the rest of those described in this section because they are not instances of same-group harassment: the targets in these cases are women, and the perpetrators are men. They do, however, reflect themes that are common to the male sexual harassment cases: first, the plaintiff manifests behaviors or qualities not associated with her biological sex, creating an ambivalent or uneasy fit with the category in which she would be placed by reference to her biology; second, this ambivalence makes it more difficult for her to recover on her claim. In some of these cases, women manifest nonconforming behaviors prior to the harassment; these behaviors appear to have been a factor that made them particular targets for harassment - that is, harassment designed to discipline their transgression of gender-role expectations. See infra text accompanying note 146 (discussing disciplinary harassment); see, e.g., Rabidue v. Osceola Ref. Co., 805 F.2d 611 (6th Cir. 1986) (considering the claims of a woman described as loud and abrasive who was a particular target of harassment by a co-worker). In Rabidue, the court not only failed to explore the possibility that Vivienne Rabidue's unfeminine behavior may have made her a target for disciplinary harassment, but also offered her abrasiveness toward the alleged offender as a ground for suggesting that the behavior at issue was more an expression of mutual personal animosity between equals than a one-sided exploitation of a sex- or rank-based power inequality. 805 F.2d at 615 .

In other cases, women are not harassed because of particular behaviors; instead, the nonconforming behaviors emerge when women are harassed. Unlike the debilitated or - often justifiably - paralyzed behavior predicted of women who suffer sexual harassment, these claimants persist in their tasks and object loudly to the perpetrators before ultimately filing legal actions. See, e.g., Harris v. Forklift Sys., Inc., 60 Empl. Prac. Dec. (CCH) If 42,070 (M.D. Tenn. 1990) (considering the claims of a plaintiff who delivered an ultimatum to the head of the company regarding his harassment and quit when his behavior failed to improve), affd. per curiam, 60 Emp. Prac. Dec. (CCH) I 42,071 (6th Cir. 1992), revd., 114 S. Ct. 367 (1993); Ukarish v. Magnesium Elektron, 31 Fair Empl. Prac. Cas. (BNA) 1315 (D.N.J. Mar. 1, 1983) (considering the claim of a plaintiff who returned the sexual epithets and conversation of her harassers and kicked one in the scrotum after a severe incident of harassment). The district court treated the plaintiff in Ukarish with considerable severity: not only did she lose her sexual harassment claim, on the grounds that her willingness to engage in the use of sexualized language with her alleged harassers indicated that their conduct was not unwelcome and her continuation on the job indicated that the harassment had not been pervasive enough to affect her psychological well-being, see 31 Fair Empl. Prac. Cas. at 1322, but she also lost a disparate treatment claim relating to her termination for fighting, though she alleged that several male employees had gotten into fights without being terminated, see 31 Fair Empl. Prac. Cas. at 1322-23. Similarly, in the district court decision in Harris, the plaintiff's willingness to remain on the job and to speak to her harasser led the courts to conclude that the defendant's behavior must not have been sufficiently pervasive to generate a hostile 
The earliest cases alleging harassment of a man by a man involved homosexual advances by a supervisor toward an employee. ${ }^{122}$ Although these cases lacked the characteristic nexus of the plaintiff's sexual victimization within the workplace and the plaintiff's group's sexual and material subordination without, ${ }^{123}$ courts still found such harassment to violate Title VII.124 Buttressed by the pronouncements of the EEOC, ${ }^{125}$ the courts held that such victims could prevail if they could demonstrate that they would not have been harassed " "but for [their] sex." "126 This formulation had the advantage of producing an appealing genderneutral symmetry, without requiring the courts to speak at length about the relationship between homosexuality and harassment. ${ }^{127}$

environment; the opinion also noted the fact that the plaintiff smoked, drank beer, and socialized with her colleagues as indicating that she was not disturbed by the environment at work. Harris v. Forklift Sys., Inc., 60 Emp. Prac. Dec. (CCH) I 42,070 (M.D. Tenn. 1990). One judicial vehicle for expressing skepticism about the plaintiff's claim has been the "serious psychological damage" requirement recently invalidated by the Supreme Court in Harris. See Harris v. Forklift Sys., Inc., 114 S. Ct. 367, 370-71 (1993). Until the Supreme Court's opinion, this requirement may have served as an instrument for marginalizing women who reflected what courts viewed as gender ambivalence in their response to sexual harassment. After Harris, courts may have the same intuition, but they no longer have the use of this particular instrument; it will be interesting to see whether this skepticism and marginalization appears in different guise.

Another case that involved a categorically ambivalent female claimant is Price Waterhouse v. Hopkins, 490 U.S. 228 (1988). In this case, a Title VII action for failure to promote, the female candidate for partner appeared to have been the target of discrimination because she combined biological femaleness with a lack of conventional femininity in dress and comportment. Yet in Hopkins, the plaintiff's categorical ambivalence seemed to make it more rather than less clear to the Court - as well as to the district court and the court of appeals - that she had received treatment that would not have been administered to a man, including the mediation of her behavior through sexist stereotypes in the evaluation process. See 490 U.S. at 255-58.

122. See, e.g., Joyner v. AAA Cooper Transp., 597 F. Supp. 537 (M.D. Ala. 1983); Wright v. Methodist Youth Servs., 511 F. Supp. 307 (N.D. Ill. 1981).

123. This nexus was initially described by Catharine MacKinnon as distinguishing and defining sexual harassment. See Catharine A. MacKinnon, Sexual Harassment of WORKING WOMEN 1-7 (1979).

124. See, e.g., 597 F. Supp. at 541; 511 F. Supp. at 310.

125. According to $\S 615.2(\mathrm{~b})$ of the EEOC Compliance manual, "[a] man as well as a woman may be the victim of sexual harassment." EEOC Compl. Man. (CCH) II 3101 (July 1987). In addition, the section notes that "[t]he victim and the harasser may be of the same sex where, for instance, the sexual harassment is based on the victim's sex ... and the harasser does not treat employees of the opposite sex the same way." Id.

126. Wright, 511 F. Supp. at 310 (quoting Barnes v. Costle, 561 F.2d 983, 990 n.55 (D.C. Cir. 1977)).

127. The larger picture with respect to homosexuality and sexual harassment is not so symmetrical. The courts seem quite willing to stop the advances of a homosexual supervisor - though it is difficult to identify these cases as gender discrimination in any sense beyond the literal "but for" definition of the courts. One explanation may be found in the misunderstanding in some early sexual harassment opinions that harassment - that is, a form of gender discrimination - is largely a matter of unrequited sexual desire. Another explanation may lie in the discomfort many straight males experience at the thought of being the object of male pursuit. For a discussion of how this discomfort has shaped the controversy 
Although the plaintiffs in these early cases did not necessarily exhibit categorical ambivalence, the cases shaped the approach of the courts to a second set of male-male cases: those in which the alleged harassment is not connected with the sexual desire of the perpetrator. In these cases, the men harassed are those who fit uneasily within established gender categories, by virtue of their aversion to sexualized talk or conduct in the workplace. The unreflective use of the "but for" test has led to a frequent failure to recognize such plaintiffs as legitimate sexual harassment claimants, despite the fact that their treatment reflects illuminating parallels with statutorily targeted forms of gender discrimination.

Two recent cases reflect this difficulty. In Polly $v$. Houston Lighting \& Power Co., ${ }^{128}$ the plaintiff alleged that he had been exposed to hostile environment sexual harassment because, inter alia, he "wouldn't get in ... [co-workers'] dirty conversations" and complained of their use of profanity at work.129 The court, rejecting the magistrate's conclusion that Title VII did not prohibit harassment of males by other males, nonetheless read the "but for" requirement into the plaintiff's showing for hostile environment sexual harassment. ${ }^{130}$ It held that in order to demonstrate that "the harassment complained of was based upon sex," Polly was obliged to show that "but for his being male, he would not have been treated

over gays in the military, see Kathryn Abrams, Gender in the Military: Androcentrism and Institutional Reform, 56 LAW \& CONTEMP. ProBs. 217 (1993).

On the opposite side of the coin, however, courts have not held the harassment of a male because he is perceived as homosexual to violate Title VII, on the grounds that this would extend protection to an intentionally uncovered group. See, e.g., Polly v. Houston Lighting \& Power Co., 825 F. Supp. 135, 137 n.2 (S.D. Tex. 1993); Ulane v. Eastern Airlines, 742 F.2d 1081 (7th Cir. 1984), cert. denied, 471 U.S. 1017 (1985); DeSantis v. Pacific Tel. \& Tel. Co., 608 F. 2d 327 (9th Cir. 1979). To the extent that discrimination against gay men is actually a form of policing of their departures from traditional gender roles, see supra note 86 , such harassment may actually embody more of the gender discrimination at which the statute was aimed than the advances of gay supervisors would. Thus, if one were willing to consider gay men to be categorically ambivalent with respect to gender, see supra note 86 , it would appear that the courts have gotten it precisely wrong in the foregoing cases. See generally Martha Chamallas, Feminist Constructions of Objectivity: Multiple Perspectives in Sexual and Racial Harassment Litigation, 1 TEX. J. WOMEN \& L. 95, 127 (1992) (noting the asymmetry in treatment of gays and lesbians as claimants and as perpetrators in sexual harassment cases).

128. 825 F. Supp. 135 (S.D. Tex. 1993).

129. 825 F. Supp. at 138.

130. The elements of a hostile environment sexual harassment claim were established by Vinson v. Meritor Savings Bank, 477 U.S. 57 (1986). The plaintiff must demonstrate that: (i) she is a member of the protected class; (ii) she was subjected to unwelcome sexual harassment in the form of requests for sexual favors or other verbal or physical conduct of a sexual nature; (iii) the harassment complained of was based on sex; (iv) the harassment unreasonably interfered with her work performance and created an intimidating, hostile, or offensive work environment; and $(v)$ there is respondeat superior liability on the part of the employer. 477 U.S. at 63-68. The "but for" test used in the cases described above applies to the third element, the required showing that the harassment was based on sex. 
by his co-workers in the manner that he was."131 The court held that Polly's allegations of the reasons for his harassment failed to demonstrate that "he was harassed by his co-workers because of his gender"132 and granted summary judgment to defendants.

Polly's distaste for and resistance to "dirty talk" in the workplace was not a conventional posture for a man. It is possible that his colleagues were discomfited by his simultaneous conformity with and departure from traditional understandings of what constitutes maleness and that this discomfort gave rise to harassing behavior. Yet the sequence of events and indeed the nature of the harassment itself are unclear from the brief opinion in Polly. These matters are more fully elaborated in an earlier case, Goluszek $v$. Smith, ${ }^{133}$ which reaches the same conclusion. Goluszek was a man from "an unsophisticated background" who "blushe[d] easily" and was "abnormally sensitive to comments pertaining to sex."134 His co-workers responded to his innocence and discomfort with a barrage of explicit sexual comments, allegations about his sexual orientation, and physical threats. ${ }^{135}$ Goluszek complained repeatedly to his supervisors about this treatment; while his complaints produced little response, he began to be cited for tardiness, improper use of equipment, and wasting time. When he was ultimately terminated for "avoidable waste of time or material,"136 he brought a Title VII action for sexual harassment and retaliatory termination.

The court granted summary judgment for defendants on the sexual harassment claim, applying and enhancing the "but for" showing required of male plaintiffs. The court acknowledged that the employer might have acted differently had Goluszek been a woman. ${ }^{137}$ Nevertheless, it held that this should not entitle Goluszek to prevail when "the defendant's conduct was not the type of conduct Congress intended to sanction when it enacted Title

131. $825 \mathrm{~F}$. Supp. at 138 .

132. 825 F. Supp. at 138.

133. 697 F. Supp. 1452 (N.D. Ill. 1988). I first read about Goluszek in Martha Chamallas's fine article, Feminist Constructions of Objectivity: Multiple Perspectives in Sexual and Racial Harassment Litigation. See Chamallas, supra note 127, at 126-31. The following discussion reflects my debt to Professor Chamallas's insight that Goluszek was "singled out for harassment because he did not conform to the men's image of male heterosexuality." Id. at 127.

134. 697 F. Supp. at 1453.

135. 697 F. Supp. at 1453-54.

136. $697 \mathrm{~F}$. Supp. at 1455.

137. See 697 F. Supp. at 1456 . The court noted that the employer would have been more likely to intervene in the harassing behavior had Goluszek been a woman; it noted one example in which a situation complained of by a woman employee had been corrected by the employer. 697 F. Supp. at 1456. 
VII."138 Congress was concerned, the court stated, about discrimination that reflected and implemented a social "imbalance of power."139 In the context of sexual harassment, this meant " the exploitation of a powerful position to impose sexual demands on an unwilling but less powerful person.' "140 Actionable sexual harassment "fosters a sense of degradation in the victim .... In effect, the offender is saying ... that the victim is inferior because of the victim's sex."141 Noting that Goluszek was "a male in a male-dominated environment," the court concluded that he "may have been harassed 'because' he is a male, but that harassment was not of a kind that created an anti-male environment." 142

Several things are noteworthy about this opinion. First, in insisting on the nexus between social disempowerment and discrimination in the workplace, the court in Goluszek imposed a requirement that courts felt free to omit in the cases involving homosexual supervisors. Second, both Polly and Goluszek suggest that to qualify as gender discrimination or sexual harassment, the behavior challenged must operate, in some respect, against all members of the protected group. In Polly, the court required proof that what happened to the plaintiff happened because he was a man: in other words, it could have happened to any man, but not to any woman. In Goluszek, the court took this categorical logic one step further: it must be treatment that not only could have happened to any man but tends to reflect negatively on men as a group or create an environment hostile to men. By contrast, neither a social nexus nor an operation against men as a group was required in Showalter v. Allison Reed Group, ${ }^{143}$ a quid pro quo case in which a supervisor coerced two male employees to participate in the sex-

138. 697 F. Supp. at 1456.

139. 697 F. Supp. at 1456.

140. 697 F. Supp. at 1456 (quoting Note, Sexual Harassment Claims of Abusive Work Environment Under Title VII, 97 HARv. L. REv. 1449, 1451 (1984)).

141. $697 \mathrm{~F}$. Supp. at 1456.

142. $697 \mathrm{~F}$. Supp. at 1456.

143. 767 F. Supp. 1205 (D.R.I. 1991). A case that provides an even more recent parallel to Showalter is Chiapuzio v. BLT Operating Corp., 826 F. Supp. 1334 (D. Wyo. 1993). In Chiapuzio a supervisor subjected both a husband and wife to sexually abusive remarks, the general import of which was that he (the supervisor) "could do a better job of making love to [the wife] than [her husband] could." $826 \mathrm{~F}$. Supp. at 1335 . The court rejected the defendant's motion for summary judgment and had no difficulty finding that plaintiff had established a genuine issue of fact as to the "but for" requirement, because the nature of the harassing remarks was specific to the gender of the target - that is, the supervisor told the woman what acts he would like to perform with her, and the man that he could perform those acts better than the man could. 826 F. Supp. at 1338. In this case, as in Showalter, the same-sex harassment might be described as incident to or connected with cross-sex, heterosexual harassment, making it easier for courts to see it as actionable. 
ual relationship between him and a female employee. In finding this conduct to be actionable sexual harassment, the court imposed no requirement that the environment appear "antimale" or that this supervisor's form of sexualization extend to men as a group. The court completely evaded the "but for" requirement by holding that the harassment of plaintiffs was on the basis of sex because it was "sexually motivated."144 Although the case is in some respects distinguishable from Goluszek or Polly, ${ }_{145}$ it reveals how easily such requirements can be dispensed with when a court sees a form of sexual harassment it finds important to address.

These cases suggest that courts are far more sympathetic to male sexual harassment claimants when they present the image of a normative, unambiguously male subject who receives unexpected sexual attention from another male in the workplace. This is attributable in part to the straight male fear of the spectral homosexual predator, though it also appears in cases like Showalter when the desired sexual conduct does not have explicit homosexual overtones. But it is also traceable to the fact that plaintiffs such as Polly and Goluszek challenge accepted notions of what it means to be a man, or a male victim of discrimination. Their combination of male characteristics - XY chromosomes, male genitalia - and what are usually thought to be female characteristics - sexual naivete or aversion to sexualized talk - seems to make the courts as uncomfortable as it makes their co-workers. The courts express this discomfort by asking whether discrimination against these claimants can be considered discrimination against men. Fueled in part by their skepticism about the male discrimination claim - reflected in the intermittent insistence on a nexus with social disempowerment - and in part by their skepticism about these males, they want a clear and unitary definition of gender discrimination against men. The holy grail in these cases is a kind of mirror image of gender discrimination against women: at the very least, the courts require

144. $767 \mathrm{~F}$. Supp. at 1211. While it is true that this element of a quid pro quo claim is framed, in the relevant precedent, as a showing that "the harassment was sexually motivated," the leading case cited by the Showalter court makes clear that this means " "but for the fact of her sex, the plaintiff would not have been the object of harassment,'" just as it does in the hostile environment context. See Chamberlin v. 101 Realty, Inc., 915 F.2d 777, 784 (1st Cir. 1990) (quoting B.T. Jones v. Flagship Intl., 793 F.2d 714, 719 (5th Cir. 1986)), cited in Showalter, 767 F. Supp. at 1211. The Showalter court's one-sentence disposition of this element suggests that it interpreted this requirement as meaning "motivated by the desire for sex." See 767 F. Supp. at 1212 ("[T] here is no question that the harassment of the plaintiffs was sexually motivated.").

145. Showalter featured the frank use of quid pro quo sexual harassment, and it managed to combine sexual treatment of a female employee with the discomfiting specter of coercion of male employees by other men. 
some form of animus that treats men as a unified group. What the courts explicitly decline to do is to look beneath biological or unitary classifications at the more complex social interactions they seek to describe and regulate. Were they to do so, they might see that not all men share unambivalently in the qualities socially connected with maleness and that discrimination by men against men does not parallel gender discrimination against women but is, in fact, strongly colored by it. What Goluszek and Polly suffered was either a form of gender discrimination against women - derision of some of the same qualities that make women targets for sexual harassment - or a form of gender discrimination against men that disciplines not the group but a distinct subset for abandoning the qualities associated with men for the more socially stigmatized characteristics associated with women. ${ }^{146}$ Despite their targeting of a different group of objects, these forms of discrimination have more in common with broadly recognized forms of gender discrimination against women, including those associated with sexual harassment, than these courts are inclined to admit.

In their response to actions by plaintiffs who claim discrimination on the basis of one characteristic but fit uneasily within the category with which it is associated, the courts have made some promising moves. They have rejected the conclusion of some magistrates that Title VII bars discrimination actions by members of the same group. They have also reflected a greater skepticism about claims by men against men than by blacks against blacks. Our society is not marked by discrimination against those qualities designated as male; those who claim to have suffered such discrimination, particularly at the hands of other men, should be required to support what might seem to be facially implausible claims. Yet to carry this reasoning too far misses what I described as the unelaborated lesson of Al-Khazraji and Shaare Tefila: that dynamics within a privileged group can take on the same racialized - or otherwise differentiated - aspect of relations between privi-

146. Chamallas explicitly endorses the first possibility and seems implicitly to favor the second as well when she notes that this situation is similar to those cases in which courts have refused to protect gay men who are harassed on the basis of their sexual orientation. See Chamallas, supra note 127, at 127-29. Because of these conclusions, Chamallas finds it unnecessary to reach the question of whether such men have any kind of nexus of workplace and societal discrimination, which might make their vantage point on sexual harassment com. parable to that of women. Id. at 128-29. Here I might go a step further and suggest that men with this ambivalent combination of gender traits are likely to have suffered in a society that enforces a narrow concept of the normatively male in a way that, while not duplicating the experience of a woman in a gendered society, at least produces some portion of the vulnerability that makes the nexus of forces particularly debilitating for women. 
leged and nonprivileged groups, just as dynamics within the disadvantaged group can be marked by the same hierarchical inflections. The search for the other that occurs even within privileged groups may mean that claimants have not suffered discrimination because they boast qualities designated as male but because, despite their biological sex, they manifest qualities socially designated as female.

In large part, courts have failed to come to terms with the complex, and often unstable, arrangement of seemingly contradictory characteristics that comprise the subjectivity of any individual. Walker can be both black and white; she may seem white to her supervisor, Ms. Lewis, but black to the white CEO of the company. Goluszek can be biologically male and socially female; this combination of traits can appear more discordant in the context of a sexualized workplace than in Goluszek's family or church. Rather than seeing such shifting combinations as a predictable characteristic of human beings, many courts treat them as anomalies to be swept under the carpet with empty analogies in Walker or Hansborough, or met with the demand for groupwide showings in the sexual harassment cases. As with the cases involving intersectional plaintiffs, these complex notions of subjectivity are not permitted to recast the courts' image of the Title VII claimant, nor are they linked to a theory of discrimination that could locate them within the world of wrongs Title VII is intended to right. How we might move toward these transformative understandings is the question to which I now turn.

\section{Discrimination and the Complex Legal Subject}

Every statutory antidiscrimination scheme is associated with a particular theory or understanding of discrimination. Title VII reflects an unusual, plural history in this regard: it has been shaped primarily by a view of discrimination derived from equality theory, and yet in recent years, it has been influenced by other theories as well. In this Part, I elaborate the dominant view, explaining how it informs the outcomes in the preceding cases and, particularly, how it has impeded recognition and accommodation of the complex legal subject. But while I highlight the elements of the dominant theory that would need to be modified in order to make central the circumstances of complex claimants, I also explore the alternate interpretations - the minor themes of Title VII enforcement - that have emerged in doctrinal contexts such as disparate impact or sexual harassment. I conclude by discussing how doctrinal areas reflecting alternative understandings of discrimination might be used 
to bring about changes necessary to respond to intersectional and categorically ambivalent claimants.

\section{A. The Dominant Account}

Title VII was enacted, and was originally litigated, under an equality-based account of discrimination. According to this theory, protected groups, such as women or racial minorities, were understood to be substantially similar to the normative group - white men - for all purposes related to employment. ${ }^{147}$ Title VII addressed the arbitrary or biased failures to recognize these similarities - failures that impeded the progress of protected groups in the workplace.

Since the early years of its enforcement, one primary form of discrimination targeted by Title VII has been any action by the employer that communicates the judgment "You shouldn't have this job because you're an $X$," when $X$ designates a protected group. ${ }^{148}$ This judgment might be spoken, in terms that relate an adverse employment decision to the plaintiff's categorical identity or to some stereotype that captures the employer's view of that identity. It might be inferable from action - from a pattern or practice in hiring, firing, or promotion that treats members of a protected group differently from the normative group. ${ }^{149}$ True to its origins in equality theory, this approach takes the differential between the subject group and the white male norm to be the most salient aspect of the judgment, so the particular imagery that is used to denigrate the group in question - and the great variability it displays - is

147. For thoughtful iterations of the equality-based account of discrimination, including but not specifically limited to the context of Title VII, see Wendy W. Williams, The Equality Crisis: Some Reflections on Culture, Courts, and Feminism, 7 WOMEN's RTS. L. REP. 175 (1982), and Richard A. Wasserstrom, Racism, Sexism, and Preferential Treatment: An Ap. proach to the Topics, 24 UCLA L. REv. 581 (1977).

148. It is this type of judgment that is the target of the McDonnell Douglas test and that is flushed out of circumspect defendants by numerical showings. See McDonnell Douglas Corp. v. Green, 411 U.S. 792 (1973).

149. Such practices may be targeted, under a disparate treatment theory, as proxies for the discriminatory judgments described above. See Alfred W. Blumrosen, Sirangers in Paradise: Griggs v. Duke Power Co. and the Concept of Employment Discrimination, $71 \mathrm{MiCH}$. L. REv. 59, 67 (1972) (presenting three concepts of discrimination, and noting that " '[u]nequal treatment' ... may be evidence of racial animus"). Unlike many accounts of employment discrimination, which distinguish primarily between disparate treatment and disparate impact concepts, Blumrosen's account identifies three concepts, effectively separating disparate treatment into two categories: "[d]iscrimination consist[ing] of acts causing economic harm to an individual that are motivated by personal antipathy to the group of which that individual is a member" and "[d]iscrimination consist[ing] of causing economic harm to an individual by treating members of his minority group in a different and less favorable manner that similarly situated members of the majority group." Id. As noted above, acts in the second category may sometimes be treated as proxies for acts in the first. 
frequently ignored. The judgments of differential competence that are the focus of this approach are viewed as being chosen, or stumbled upon, by the fully formed subjects who hold them; they have little role in constituting either the perpetrators or their victims. This approach also presents each discriminatory judgment as if it were held in analytic and epistemological isolation from other judgments about the differential capacity of groups. This premise or appearance of isolation can be maintained because the relationships between the judgments that operate in the workplace and constellations of discriminatory attitudes and structures that pervade social life beyond the workplace are never systematically discussed. ${ }^{150}$

The advent of Griggs v. Duke Power Co. ${ }^{151}$ and the disparate impact standard worked some changes in this understanding. Judgments of differential capacity ceased to be the exclusive touchstone of Title VII cases: the statute also targeted facially neutral employment standards or practices that erected disproportionate barriers to protected groups, unjustified by business necessity. ${ }^{152}$ This broadened the focus from employer prejudice to insensitive or motivationally innocent institutional arrangements that perpetuated the effects of longstanding societal discrimination. ${ }^{153}$ It looked beyond the workplace to glimpse one form of interaction between employment practices and larger patterns of discrimination. ${ }^{154}$

Disparate impact is not, moreover, the only area of Title VII doctrine that has diverged from the equality-based disparate treat-

150. One factor in the reluctance to draw connections between workplace and broader social discrimination may be a concern that an emphasis on society-wide patterns is the first step toward the justification of race- or gender-conscious relief by reference to societal discrimination. For thoughtful progressive critiques of the societal-discrimination strategy for justifying race- or gender-conscious remedies, see Drew S. Days III, Fullilove, 96 YALE L.J. 453 (1987), and Kathleen M. Sullivan, Sins of Discrimination: Last Term's Affirmative Action Cases, 100 Harv. L. Rev. 78 (1986). While I am less skeptical of "societal discrimination" justifications for race- and gender-conscious remedies than Sullivan and Days are, I do not believe that these justifications would inevitably be entailed by an effort to connect discrimination in the workplace to discrimination in the social world beyond.

151. 401 U.S. 424 (1971).

152. 401 U.S. at 429-33; see also Blumrosen, supra note 149, at 78-81. For an interestingly distinct view of Griggs, see George Schatzski, United Steelworkers of America v. Weber: An Exercise in Understandable Indecision, 56 WASH. L. REv. 51, 61-63 (1980) (arguing that the decision to focus on employment criteria that are not discriminatorily motivated reflects a desire for a more racially balanced workforce).

153. See Blumrosen, supra note 149 , at 71 . For a discussion of why racially selective insensitivity violates the antidiscrimination principle, in employment discrimination and elsewhere, see Paul Brest, The Supreme Court, $1975 \mathrm{Term}$ - Foreword: In Defense of the Antidiscrimination Principle, 90 HARv. L. Rev. 1 (1976).

154. For a more complete discussion of this feature of the disparate impact approach, see infra notes $174-83$ and accompanying text. 
ment framework. The Pregnancy Discrimination Act (PDA), ${ }^{155}$ though framed in the equality-based terms of the primary statutory guarantee, requires employers to accommodate the difference of a protected group; ${ }^{156}$ the same can be said of Title VII's requirement of reasonable accommodation of religion. ${ }^{157}$ Sexual harassment claims reflect perhaps the greatest divergence from the dominant understanding: they address those abuses of power that import the sexualized domination of women that pervades the larger society into the employment context. Not only do they target a form of discrimination that involves more than judgments of differential capacity; they view discrimination in the workplace as replicating and complicating patterns of discrimination enacted elsewhere - patterns that shape the self-understanding of those they victimize. ${ }^{158}$

Yet, notwithstanding their variety, all these understandings of discrimination under Title VII partake, to a greater or lesser extent, of several assumptions. These assumptions help to explain the outcomes in those cases involving complex claimants surveyed above. First, Title VII doctrine assumes that the members of a protected group are easily identifiable. Characteristics such as race and gender are understood to be biologically given, ${ }^{159}$ and biological trans-

155. The Pregnancy Discrimination Act, Pub. L. No. 95-555, 92 Stat. 2076 (1978) (codified at 42 U.S.C.A. 2000e(k) (1988)), provides that sex discrimination includes discrimination on the basis of pregnancy. The PDA was an amendment to Title VII added to respond to the Supreme Court's decision in General Electric Co. v. Gilbert, 429 U.S. 125 (1976).

156. The justification for this accommodation may be expressed in equality-based terms as well; it permits women, as well as men, to combine family life with workforce participation. See California Fed. Sav. \& Loan Assn. v. Guerra, 479 U.S. 272, 289 (1987).

157. The extent of this accommodation, however, remains a matter of doctrinal controversy. See, e.g., Trans World Airlines v. Hardison, 432 U.S. 63 (1977) (addressing the extent of accommodation required of the employer of a sabbatarian).

158. See, e.g., MACKINNON, supra note 123, at 1-23. For a more complete discussion of the divergent assumptions of sexual harassment doctrine, see infra notes 140-83 and accompanying text.

159. Biological transmission is usually understood to be the source of the immutability that is often invoked to justify the legal protection of such characteristics. See Owen M. Fiss, A Theory of Fair Employment Laws, 38 U. CHI. L. REv. 235, 241-42 (1971) (discussing the absence of individual control over race as justifying a prohibition on the use of racial criterion for employment decisions); see also Schatzski, supra note 152, at 55. Some alternative accounts of discrimination have involved notions of protected characteristics that are not biologically grounded. See Owen M. Fiss, Groups and the Equal Protection Clause, 5 PHIL. \& PUB. AFF. 107, 147, 155 (1976) (stating that some "social groups" protected under "groupdisadvantaging principle" may be defined in terms of characteristics that are neither biological nor immutable, such as alienage). Another example of the assumption that race - or gender - is a biologically given rather than socially constructed characteristic may be found in cases regarding hairstyle. See Paulette Caldwell, $A$ Hair Piece: Perspectives on the Intersection of Race and Gender, 1991 DuKE L.J. 365. In discussing Rogers v. American Airlines, 527 F. Supp. 229 (S.D.N.Y. 1981), and other cases in which courts have upheld employers' prohibitions on braided hairstyles as not constituting discrimination on the basis of race, Caldwell argues that the courts' conception of race is almost exclusively biological. Caldwell, supra, at 378 ("Braids . . . are . . . a cultural practice - and are therefore mutable, i.e., the 
mission is in turn associated with fixity and lack of ambiguity. There is always the possibility of a claimant who reflects a mixed biological legacy, as in Walker, or whose appearance does not reflect what is conventionally understood to be his biological endowment, as in Plessy v. Ferguson. ${ }^{160}$ But such cases are regarded as exceptional and are usually dispatched by recourse to some readily applicable rule. ${ }^{161}$ Thus, even in the context of sexual harassment, the biological understanding of protected characteristics makes it difficult for courts to see in claims of men like Polly or Goluszek the kinds of gender discrimination Title VII proscribes. ${ }^{162}$

Second, in order to be considered discrimination against group $X$, the employer's judgment $\longrightarrow$ which may posit employmentrelated incapacity or generalized inferiority (disparate treatment, sexual harassment) or reflect insensitivity to the group's social circumstances (disparate impact) - must be applicable to the group as a whole. ${ }^{163}$ Discriminatory judgments are understood to apply to the group as a whole when they are applicable to all subgroups or are aimed at persons who are not distinguished by any group-based characteristics other than that designated $X .{ }^{164}$ Because all people have many such characteristics, these paradigmatic persons are likely to be those whose non- $X$ characteristics are accorded sufficient privilege to render them invisible for statutory purposes - for

result of choice."). Because the black female worker can alter her hairstyle - regardless of the cost of such mandatory alteration for her culturally defined sense of racial identity employers are permitted to proscribe the wearing of braids. Id. at 378-79.

160. 163 U.S. 537 (1896). Plessy argued that he was "seven[-]eighths Caucasian and one[-]eighth African blood; that the mixture of colored blood was not discernible in him, and that he was entitled to every recognition, right, privilege and immunity secured to the citizens of the United States of the white race." 163 U.S. at 538. The fact that he was viewed as black according to conventional norms of the time, however, is suggested by the fact that he was arrested for refusing to vacate his seat in a railway coach reserved for whites. For a fascinating discussion of this element of Plessy's challenge in relation to his broader challenge to the system of segregation, see Crenshaw, supra note 18, at 1298.

161. For example, the Court in Plessy held that the issue of Plessy's proper racial classification was a matter of state law. See 163 U.S. at 552.

162. See supra section II.B.2.

163. See Blumrosen, supra note 149 , at 72 ("Discrimination of the type prohibited by Title VII is a class- or group-oriented phenomenon that challenges the status of every member of the class."). Blumrosen notes that this feature of the discrimination targeted by Title VII has become particularly apparent with the advent of the disparate impact approach. Id.. A notion that actionable discrimination operates against a group as a whole also appears to be implicit in Brest's "antidiscrimination principle," which targets actions or decisions that "seem[] to refiect assumptions of racial inferiority or selective indifference and ... seem[] likely to inflict stigmatic injury or add to cumulative harms." Brest, supra note 153, at 21.

164. See Crenshaw, Demarginalizing the Intersection of Race and Sex, supra note 25 , at 143-46 (discussing the reluctance of courts to certify black women as class representatives in cases alleging gender discrimination because of concerns that what they have suffered is not characteristic of the discrimination suffered by "women" in a particular workplace). 
example, white women are only distinguished by gender, but Latina women are distinguished by race and gender. There are times when discrimination against a subgroup may be targeted under Title VII law: the "sex-plus" doctrine is a good example. ${ }^{165}$ But doctrines such as sex-plus function less as means of recognizing the variable and highly contextualized faces of gender discrimination than as means of preventing the strategic deployment of ostensibly neutral categories, such as marriage or parental status, to defeat the more general purposes of the statute. ${ }^{166}$ When Title VII does target discrimination against a subgroup, its goal is understood to be ancillary to, and less important than, stopping the implementation of discriminatory judgments applicable to the group as a whole. For example, the sex-plus doctrine can easily be cabined, as in Judge $v$. Marsh, ${ }^{167}$ without undermining the force or direction of Title VII enforcement.

Third, actions or judgments that are most readily understood to be discrimination against group $X$ are made by members of another group. ${ }^{168}$ Discriminatory judgments arise from irrational animus,

165. See supra notes 54-58 and accompanying text.

166. Explaining the purpose of the sex-plus doctrine, the court in Jefferies cited Judge Brown's dissent from the Fifth Circuit's decision and denial of rehearing in Martin Marietta. Jefferies v. Harris County Community Action Assn., 615 F.2d 1025, 1033 (5th Cir. 1980) (citing Phillips v. Martin Marietta Corp., 416 F.2d 1257, 1260 (5th Cir. 1969) (Brown, J., dissenting from denial of rehearing)). The Fifth Circuit's opinion was ultimately reversed by the Supreme Court. Phillips v. Martin Marietta Corp., 400 U.S. 542 (1971). The Jefferies court endorsed Judge Brown's conclusion that refusal to consider sex-plus discrimination under Title VII would "completely undermine the Act." 615 F.2d at 1032. " "Free to add non-sex factors, the rankest sort of discrimination against women can be worked by employers. This could include, for example, all sorts of physical characteristics, such as minimum weight ...., minimum shoulder width, minimum biceps measurement, minimum lifting capacity . . . and the like." " 615 F.2d at 1033 (quoting 416 F.2d at 1260). Judge Brown's concern seems to be either that employers would deploy ostensibly neutral criteria that actually captured the vast majority of the female sex - such as shoulder width, biceps measurement, and lifting capacity - or that employers. would deploy one, possibly pretextual, neutral category after another until most women were covered.

167. 649 F. Supp. 770 (D.D.C. 1986); see supra notes $61-62$ and accompanying text.

168. My argument here is not that there is any statutory or judge-made rule preventing recognition of discrimination among members of the same statutory group. In fact, cases such as Walker and Hansborough, and EEOC advisories such as the sexual harassment Compliance Manual discussed supra in note 125, indicate that legal decisionmakers are, on occasion, willing to acknowledge the possibility of discrimination within a statutory group. My point is that such patterns of discrimination are treated as anomalous or inherently problematic as the basis for Title VII claims. There is an initial assumption of implausibility that a plaintiff seems to be required to defeat in order to prevail; this is indicated most clearly in a case such as Hansborough, which imposes an enhanced burden of proof on a plaintiff who would allege intragroup discrimination. See supra notes 103-10 and accompanying text. My point is that this entrenched doctrinal skepticism about intragroup discrimination reflects both sound reasoning - because members of the same statutory group may have similarities in background and socialization, there is some reason to believe that disputes among them may be attributed to personal animosity rather than group-related animus - and unsound reasoning - because courts have treated group membership as an unambiguous question to 
ignorance, or error. There is little reason to believe that a person would be ignorant, mistaken, or intolerant of qualities he possesses himself, particularly when his attitudes are not understood to be integrally shaped by any broader social structures. Thus, when a judgment against a person in group $X$ is made by another person in group $X$, it is assumed to be the result of personal antagonism, rather than group-based beliefs. This assumption seems to animate the skeptical demand for antimale animus in the Goluszek case. ${ }^{169}$ The courts have strayed from this assumption in particular cases: Walker, for example, permitted a departure because the category $X$ - race - could be subdivided and adjudicated according to another protected category - color. ${ }^{170}$ But the necessity of this reclassification, or of the imposition of additional burdens of proof in cases such as Goluszek and Hansborough, ${ }^{171}$ suggests the importance of the general rule: cases that depart from the assumption of discrimination as an intergroup phenomenon are treated as anomalous and are circuitously or unsatisfactorily explained.

A fourth assumption, reflected more fully in the dominant understanding of discrimination, is that discriminatory actions or judgments are workplace-specific barriers that hinder employment opportunity, rather than parts of a larger system of discrimination that shapes the consciousness of those subject to it or intersects with other systems of discrimination. Under the equality theory that informs disparate treatment law, individuals are formed prior to social interaction. If these individuals are perpetrators of discrimination, they assume discriminatory attitudes through ignorance, irrationality, or conscious choice; if they are victims, they

\footnotetext{
be resolved by reference to biology, they have missed many kinds of ambivalence inherent in group membership that are capable of producing harmful discriminatory dynamics among people ostensibly within the same statutory group. My goal in this essay is to expose and address the portion of judicial skepticism on this point that is attributable to unsound reasoning. The inquiry I propose is sufficiently contextual, see infra section III.B.2, that it seems unlikely to produce significant overprotection of intragroup discrimination - that is, findings of intragroup discrimination in cases where non-group-based interpersonal animosity is a better explanation - although this is always a possibility when new categories or subcategories of conduct are made actionable. A recent Supreme Court decision that seems to employ the assumption that discrimination on the basis of a protected trait does not occur among members of the same (protected) group is St. Mary's Honor Center v. Hicks, 113 S. Ct. 2742 (1993). In concluding that the plaintiff had not been demoted and discharged on the basis of race, both the district court and Justice Scalia's majority opinion for the Supreme Court place emphasis on the fact that two blacks sat on the disciplinary review board that recommended disciplining the plaintiff, who was also black. See 113 S. Ct. at 2748 n.2; Hicks v. St. Mary's Honor Ctr., 756 F. Supp. 1244, 1252 (E.D. Mo. 1991).
}

169. See supra notes $133-42$ and accompanying text.

170. See supra notes $91-117$ and accompanying text.

171. See supra notes 103-10 and accompanying text. 
encounter these attitudes as impediments to their at least partially autonomous progress through the workplace. ${ }^{172}$ In neither case do these attitudes, in any important sense, constitute the self-conception or subjectivity of those who hold them. Judges and advocates who embrace this view make no effort to link discriminatory judgments in the workplace to those that operate outside, beyond observing that they may be animated by similar ignorance or prejudiced irrationality. To look for social patterns that are not specifically traceable to the judgments of particular individuals is to depart from the focus on individual human agency that is assumed to be the predicate of legal responsibility. ${ }^{173}$

Disparate impact and sexual harassment law attempt to connect discrimination in the workplace to larger social patterns; they see discrimination as perpetrated by interactions more various than the culpable actions of individuals. Yet neither body of doctrine has offered a developed - or even explicit - account of the participation of a range of institutions, including the workplace, in social patterns of discrimination; and neither has described, in more than general terms, the ways that systems of discrimination shape or constitute those who are subject to them.

Disparate impact doctrine has highlighted a link between discrimination in the workplace and in the larger social world: it describes the way that practices in the workplace may perpetuate, or freeze in place, discrimination enacted in other social institutions. ${ }^{174}$ Yet the doctrine suggests only one of many possible relations. Moreover, its emphasis on the motivational innocence of the employer $^{175}$ and its marginalization within antidiscrimination doctrine

172. For an account of discrimination that closely reflects this view, see Wasserstrom, supra note 147.

173. See Fiss, Groups and the Equal Protection Clause, supra note 159, at 145. Fiss argues that under the dominant understanding of discrimination, a practice of means-ends scrutiny he refers to as the "antidiscrimination principle," arguments that emphasize social - or "global" - patterns of discrimination by invoking "past discrimination" sever "connections between victim and beneficiary and between past perpetrator and present cost-bearer." Id. This inevitably weakens such arguments because they have "ceased ... [to be] about the perpetuation of past discrimination in any individualized sense." Id. The assumption that there should be individualized responsibility for discrimination is not a feature of the dominant approach with which Fiss necessarily agrees, but he sees it at the heart of the current antidiscrimination enforcement regime. In the article cited, Fiss is referring primarily to the Equal Protection Clause when he discusses antidiscrimination law, yet the general principles he articulates are relevant to Title VII law, particularly in the area of disparate treatment and more generally in the sense that remediation under Title VII is limited by the Fourteenth Amendment.

174. See Blumrosen, supra note 149, at 70; Fiss, $A$ Theory of Fair Employment Laws, supra note 159, at 239.

175. This is not in all respects a drawback: permitting recovery in the context of motivational innocence lightens the burden on the plaintiff and suggests that even those who do not 
as a whole ${ }^{176}$ have prevented it from stimulating inquiry into other ways in which employment discrimination may exploit or replicate social patterns. Sexual harassment doctrine has been suggestive of other relations between the workplace and the larger society: harassment is sometimes described as exacerbating women's sexual subordination by linking it to their economic disempowerment, ${ }^{177}$ or as importing into the ostensibly level ground of the workplace the sexual subordination that characterizes other social contexts. ${ }^{178}$ But courts have not consistently placed this social constructivist gloss on the sexual harassment claim. Sometimes sexual harassment is construed as a more straightforward violation of women's equality: Justice Ginsburg's recent opinion in Harris v. Forklift Systems, Inc. 179 describes harassment as making it " 'more difficult" " for women, as opposed to men, to perform their assigned jobs. ${ }^{180}$ Moreover, judicial recourse to social context is not always associated with liberatory goals: some courts have cited the level of sexualized abuse observable in society at large to deny plaintiffs' claims of injury. ${ }^{181}$ And only in the invocation of the "reasonable woman" standard - a standard recently rejected by the Supreme Court ${ }^{182}$ - does one see a clear suggestion that the subject is influenced or

hold prejudiced attitudes can perpetuate discrimination - both important assets in the broadening of employment protections.

176. This marginalization has been effected largely through judicial interpretation of the Equal Protection Clause of the Fourteenth Amendment. See Washington v. Davis, 426 U.S. 229 (1976) (rejecting a constitutional disparate impact claim and insisting on a showing of discriminatory motivation). For a thoughtful effort to ground the disparate impact approach according to the norms of the preexisting antidiscrimination paradigm, see Brest, supra note 153. To the extent that Schatzski is correct that the disparate impact approach reflects an effort to implement affirmative action, see supra note 152, it may also have been marginalized by constitutional doctrine contracting the scope of race-conscious remedies. See, e.g., City of Richmond v. J.A. Croson Co., 488 U.S. 469 (1989); Regents of Univ. of Cal. v. Bakke, 438 U.S. 265 (1978).

177. See, e.g., MacKinnon, supra note 123, at 1-23.

178. See, e.g., GuTEK, supra note 3, at 133-37; Kathryn Abrams, Gender Discrimination and the Transformation of Workplace Norms, 42 VAND. L. REv. 1183, 1202-09 (1989); Note, supra note 140, at 1451-52. This view is also articulated in some cases, including those that ultimately articulate restrictive views of actionable sexual harassment. See, e.g., Goluszek v. Smith, 697 F. Supp. 1452, 1456 (N.D. Ill. 1988) (describing sexual harassment as involving the exploitation of previously existing power inequalities).

179. 114 S. Ct. 367 (1993).

180. 114 S. Ct. at 372 (quoting Davis v. Monsanto Chem. Co., 858 F.2d 345, 349 (6th Cir. 1988)).

181. See e.g., Rabidue v. Osceola Ref. Co., 805 F.2d 611, 622 (6th Cir. 1986) (denying recovery when the extent of pornographic display did not seem excessive in light of representations to which women are frequently exposed outside the workplace).

182. See, $114 \mathrm{~S}$. Ct. at 370 (holding that Title VII targets harassing conduct that is severe or pervasive enough to create "an environment that a reasonable person would find hostile or abusive" (emphasis added)). 
shaped by discrimination to the point that her perceptions of particular conduct may differ from those of the normative group. ${ }^{183}$

The reluctance of courts - across the range of Title VII doctrines - to make explicit the ways that systems of discrimination operate and intersect, or shape the consciousness of the subject, has created a doctrine that is blind to many discriminatory dynamics. It makes judges capable, in cases like Walker, of describing discrimination on the basis of "color" or "ethnicity" as distinct phenomena not integrally connected to race. A discriminatory judgment about group $X$ is an individual expression of ignorance or predilection: it is not shaped by broader social attitudes about $X$, through which one might uncover links to attitudes about $Y$ or $Z$. Such a doctrine is also capable of placing intragroup conduct, such as that in Golus$z e k$, beyond the pale of coverage. Because it fails to focus on social patterns of discrimination or the ways that such discrimination shapes the subject, it neglects the sense in which action within a given group may reflect devaluation of, or a need to assert a hierarchical relation to, those outside it.

\section{B. The Challenge of Complex Claimants}

Illuminating these four assumptions underlying Title VII doctrine - (i) that protected traits are biologically transmitted, (ii) that discriminatory judgments are broadly applicable, (iii) that discrimination is an intergroup phenomenon, and (iv) that discrimination is specific to the workplace and distinct from broader social patterns explains many things about the cases involving complex legal subjects. It explains why discrimination against a multiply constituted subgroup looks anomalous - a partial phenomenon not to be confused with the real thing. If generality of application is one of the distinguishing features of group-based discrimination and the paradigmatic victims are distinguished from the norm only by the possession of a single, stigmatized trait, then more focused forms of discrimination, targeting groups that are multiply marked, are bound to seem distinct, as matters of local rather than more universal interest. Similarly, if discriminatory judgments about particular groups are thought to be distinct, lacking the grounding in social structures or configurations that might establish connections or parallels between them, it is hardly surprising that aggregation -

183. For thoughtful elaborations of how the reasonable woman's perspective is socially constructed, in salient part through the experience of gender oppression, see Ellison v. Brady, 924 F.2d 872, 878-81 (9th Cir. 1991); Lehmann v. Toys 'R' Us, 626 A.2d 445, 475-79 (N.J. 1993) (involving a New Jersey state analog to Title VII). 
rather than interaction or intersection - is the main way courts have seen fit to deal with claims by women of color. These features of the dominant account of discrimination also help to explain why the categorically ambivalent, who cite discrimination by members of their own groups, are treated as oddities who must surmount exceptional barriers of proof in order to prevail on their anomalous claims. This view of discrimination takes membership in a statutory group as biologically given and permanently fixed; it contains no explanation of how distinctions might arise within groups or of how group members might come to devalue those who are facially or substantially similar. These points of tension should lead us to ask: What changes in this view of discrimination would be necessary to make such complex claimants mainstream rather than marginal players in Title VII doctrine and to provide a full account of the kinds of discrimination they suffer?

\section{Conceptual Shifts}

Modifying the four assumptions enumerated above requires legal advocates and decisionmakers to revise their views of two critical concepts: the nature and operation of discriminatory judgments, and the characteristics that statutory categories are intended to protect. Underlying each of these reconceptualizations, however, is a vision of the social construction of the subject, and the role of discrimination in that process, that must also be implemented in order fully to accommodate the complex subject.

a. The nature and operation of discriminatory judgments. The first set of necessary changes concern the nature and operation of discriminatory judgments: how they arise, how they are connected to other structures of oppression or systems of belief, how they shape those who hold them and those to whom they are applied. In order for courts squarely to address the claims of the complex subject, they must reconceive discrimination, not as a judgment of contrasting capacity that is offered to justify differentiation, but as a judgment of devaluation that effects disempowerment. Catharine MacKinnon has played a pivotal role in shifting the emphasis in discussions of gender discrimination from a focus on women's differences from men to a focus on men's domination of women through sexual objectification. ${ }^{184}$ While this analysis has informed some portions of sexual harassment doctrine, it has yet to reach the

184. See Catharine MacKinnon, Difference and Dominance, in Feminism UnmodiFIED, supra note 8 , at 32 . For a complementary argument grounded in the social sciences, see SANDrA L. Bem, The Lenses of Gender (1993). 
basic understandings beneath many areas of Title VII law. The question in these areas is still whether an employer has expressed a judgment of differential capacity, not how such judgments shape the institutional position and self-conception of affected employees. As decisionmakers shift their focus to judgments of devaluation that justify and effect disempowerment, including judgments of differential capacity, it will be easier to observe themes and patterns in devaluative imagery that will enhance the understanding of intersectional discrimination.

One important theme is the variability and malleability of those judgments by which outsider groups are devalued. Not only are perpetrators capable of modifying the forms of their derision when certain kinds of judgments are proscribed by a legal antidiscrimination regime - a pattern, for example, that has made undisguised judgments of the form "you shouldn't do this job because you're an $X$ " increasingly rare. But apart from the effects of regulation, devaluation assumes many guises that often track the specific characteristics of its targets. ${ }^{185}$ Women may be described as overly emotional or irrational, as vessels for the bearing of the next generation, as moral mothers unfit to withstand the insults of an ugly public world, as lazy dependents on government largesse, as innocents whose sexual purity requires male protective vigilance, as willful or promiscuous manipulators of male sexuality. As the last two descriptions indicate, such characterizations may take the form of a dichotomy, in which each pole is devalued in distinctive fashion. New characterizations and dichotomies may also emerge in relation to salient social changes: the surge in professional women in

185. For thoughtful feminist accounts that describe gender discrimination as consisting of multiple discriminatory strategies or devaluative images, see MARY JOE FRUG, POSTMODERN LEGAL FEMINISM 129-31 (1992) (describing the terrorization, maternalization, and sexualization of women and female bodies), and Christine A. Littleton, Equality and Feminist Legal Theory, 48 PITr. L. REv. 1043, 1045-46 (1987) (describing women as subject to sex discrimination, gender oppression, and sexual subordination).

Interestingly, a related argument may be found in the later work of Catharine MacKinnon. Responding to arguments that the unity of her theory of sexualized domination excludes the experiences of minority women, MacKinnon argues that there is particularization by race and other characteristics even within the dynamic of sexualized oppression:

The treatment of women in pornography shows this approach in graphic relief. One way or another, all women are in pornography. African-American women are featured in bondage, struggling, in cages, as animals, insatiable. . . . Asian women are passive, inert, as if dead, tortured unspeakably. Latinas are hot mommas. Fill in the rest from every demeaning and hostile racial stereotype you know; it is sex here. ...

I am saying, each woman is in pornography as the embodiment of her particularities. This is not in tension with being there "as a woman," it is what being there as a woman means. Her specificity makes up what gender is.

Catharine MacKinnon, From Practice to Theory, or What Is a White Woman Anyway?, 4 YALE J.L. \& Feminism 13, 20-21 (1991). 
the workplace has been accompanied by new dichotomies, such as the insufficiently assertive female versus the aggressive bitch, ${ }^{186}$ or the ruthless, childless career woman versus the unreliable workand-family woman. ${ }^{187}$ Gender discrimination may insinuate itself into other oppressive frameworks by particularizing - for example, by sexualizing - the devaluative images applied to a group not primarily defined by gender. For example, black feminist theorists have described the ways in which the animalistic metaphors used to dehumanize blacks have been infused with sexual particularity to construct black men as predators and black women as insatiable and promiscuous. ${ }^{188}$ Thus, a glimpse at the range of images through which subordination occurs reveals both variation and common themes: a similarity of devaluative practices across different groups, and intersection and mutual reinforcement among different systems of discrimination.

Understanding discrimination as devaluation, however, means more than noting the varied forms that it takes. It also means understanding the way it effects the disempowerment of its subjects. This understanding in turn requires a more constructivist view of the formation of the subject, as well as of the effects of discrimination. The dominant approach posits a world of fully formed beings, who either embrace or are thwarted by opinions of differential capacity. The move toward discrimination as devaluation requires an understanding of the way discrimination helps form the subject. Devaluative imagery employed in the workplace rests on and resonates with a complicated system of cultural myths, images, and stereotypes, which are reflected in many other social institutions and practices. ${ }^{189}$ An employer who refers to a female worker as a "nice

186. Mary Radford offers a useful discussion of the way in which both sides of this dichotomy have been subject to devaluation in the contemporary workplace. See Mary F. Radford, Sex Stereotyping and the Promotion of Women to Positions of Power, 41 Hastings L.J. 471, 487-89 (1990) (providing a hypothetical illustrating the multidimensional character of sex stereotyping, and suggesting that even a single person may occupy both sides of the dichotomy, being seen by some as too abrasive and by others as too emotional).

187. Anna Marie Smith has argued that, particularly as reflected in recent films such as Fatal Attraction (Paramount Pictures Corp. 1987) or The Paper (Universal Studios, Inc. 1994), the well-rounded family woman versus the childless career woman is the contemporary recycling of the "madonna versus whore" dichotomy. Conversation with Anna Marie Smith, Assistant Professor of Government, Cornell University, in Ithaca, N.Y. (Feb. 3, 1994).

188. See Crenshaw, Whose Story Is It Anyway?, supra note 25, at 411 (discussing images of black women as "sexually voracious," "sexually indiscriminate," and amenable to copulation "with animals ... apes and monkeys"); Jacquelyn D. Fall, "The Mind that Burns in Each Body": Women, Rape and Racial Violence, in THE POWERs OF DEsIRE 328, 334 (Ann Snitow et al. eds., 1983) (discussing an image of a " "black rapist" " as " 'a monstrous beast, crazed with lust" " (quoting Charles H. Stember, Sexual Racism 23 (1976))).

189. This understanding is articulated throughout the literature of feminism and critical race theory. For thought-provoking examples, see Crenshaw, Whose Story Is It Anyway?, 
piece" or derides her as a "dumb bitch" is not originating novel images; he is invoking images with elaborate resonance in the familial, social, or educational experience of most women in this society. ${ }^{190}$ Sustained exposure to these images in a variety of contexts shapes our vision of ourselves. If we are the targets of such imagery, it causes us to second-guess our interpretation of our actions; ${ }^{191}$ it limits our sense of our possibilities by making some choices more plausible than others. ${ }^{192}$ If we are the perpetrators or beneficiaries of such imagery, it also shapes our self-conceptions. This backdrop of cultural imagery not only establishes our position in the social hierarchy but also shapes the opinions we hold. Devaluative or discriminatory assumptions are not simply chosen by us, as equality theorists sometimes suggest, because they already influence the environment in which we exercise choice, ${ }^{193}$ making

supra note 25; Williams, supra note 9; Charles R. Lawrence III, The Id, the Ego, and Equal Protection: Reckoning with Unconscious Racism, 39 STAN. L. Rev. 317 (1987). It is also a central premise of recent literature advocating the regulation of pornography or hate speech. See Catharine A. MacKinnon, Only Words (1993); Mari J. Matsuda et Al., Words That Wound (1993).

190. Another recent example of such a practice arose during the struggle over the nomination of Lani Guinier as head of the Civil Rights Division of the Justice Department. Opponents of Guinier widely characterized her as a "quota queen": not only did the factually incorrect suggestion of Guinier's commitment to quotas suggest an effort to create resonance with the highly controversial policy of affirmative action, but the use of the term queen utterly unnecessary beyond its feeble alliterative value - reflected an attempt to associate Guinier with welfare queens - a category of ostensibly undeserving, largely black beneficiaries of the government's statutory largesse. For a discussion of the negative imagery surrounding the recipients of welfare, see Nancy Fraser, Unruly Practices: Power, Discourse, and Gender in Contemporary Social Theory 151-56 (1989).

191. For example, the concern or worry reported by many women that they are somehow implicated in their own sexual harassment or coercion is in part attributable to cultural narratives that emphasize women's control over and manipulation of male sexuality. For striking iterations of such narratives by contemporary men, see Timothy BENEKE, MEN ON RAPE (1982).

192. For a wonderfully illuminating example, see Leslie G. Espinoza, Masks and Other Disguises: Exposing Legal Academia, 103 HARv. L. Rev. 1878, 1878 (1990) (relating her childhood fear that despite her efforts and ambitions she would grow up to be a hairdresser, like all the other women in her Latino family). I also like Espinoza's story because its ending - she ultimately became a law professor - illustrates that the force of such social expectations, while strongly influential, is not wholly determinative of the actions of those subject to it.

193. My suggestion here is that such structures of discrimination, while formative and constraining, do not wholly exclude the possibility of agency on the part of those subject to them. Rosemary Coombe and Vicki Schultz have referred to such structures "not [as] "barriers' to human activity but rather the 'fields' in which that activity occurs" - stressing also that the "'fields' themselves exist only as the product of [collective] human creation." See Vicki Schultz, Room to Maneuver (f)or a Room of One's Own? Practice Theory and Feminist Practice, 14 LAw \& Soc. InQuiRy 123, 135-36 (1989) (citing Rosemary J. Coombe, Room for Manoeuver: Toward a Theory of Practice in Critical Legal Studies, 14 LAW \& Soc. INQuIRY 69,90 (1989)). Schultz acknowledges the constraint imposed by such fields but also highlights the possibilities of agency within them, particularly when exercised through collective action. Id. at 137-44. Thus, she urges theorists to go farther than Coombe's "deconstruct[ion of] structure" to attend to the range of contextual factors that make it easier for some groups 
some descriptions, images, and hierarchies appear more coherent than others. ${ }^{194}$ Viewed in this way, employment discrimination represents, not a chosen course of institutionally specific conduct, but a reiterative practice that further enmeshes us in, and shapes us according to, oppressive social patterns.

Reconceiving discrimination in these ways would offer many insights germane to the circumstances of complex claimants. ${ }^{195}$ It would suggest, first, that there is no ground for privileging, in an antidiscrimination regime, discriminatory judgments that are general in their application to a group. Although some of the images through which women are devalued and socially or politically dominated apply to the entire group, much of the power of gender discrimination as a system arises from its particularity and variability - its capacity to encompass and explain many different groups of women. Thus judgments that apply to some women - be they sexually active women or mothers or black women - are equally important to the system of discrimination, and especially gender discrimination, despite their particularity. ${ }^{196}$ Second, reconceiving discrimination would help explain how some compound forms of discrimination are intersectional rather than merely aggregative. ${ }^{197}$

or actors than others to exercise such resistant agency. Id. It is this sort of image, of contextually differential agency within systematic constraint, that I mean to convey when I refer to "social construction."

194. Kimberlé Crenshaw explains, for example, how the white solipsism of feminist discourse and the androcentrism of antiracist discourse made Anita Hill's account of the harassment of a black woman unintelligible to many of her listeners. See Crenshaw, Whose Story Is It Anyway?, supra note 25, at 402-04. I thank Anna Marie Smith for helping me to understand Crenshaw's argument in this light.

195. In particular, it would revise the second conception - discrimination applies to a group as a whole - and the fourth - discrimination represents a workplace-specific barrier, rather than part of larger system of discrimination that helps construct the subject - of the assumptions that have made it difficult for courts to address the claims of intersectional subjects.

196. A conceptual shift that made discrimination affecting subgroups less exceptional and more paradigmatic of the kind of injury at which Title VII is aimed might be particularly important in hiring, firing, and promotion cases framed under a disparate impact theory. In these cases, the "business necessity" defense invites courts to engage in more of a balancing analysis than is frequently the case in disparate treatment litigation, when defendants' primary recourse is to the fairly narrow "bona fide occupational qualification" exception. A conceptual account that, in contrast to the current sex-plus doctrine, explained why such narrowly targeted discrimination was neither unusual nor less serious but in fact paradigmatic of gender or race discrimination would permit complex claimants to fare better when their injuries came to be balanced against employers' necessity claims.

197. A qualitative understanding of intersectional discrimination might be of assistance, for example, to complex - that is, intersectional - claimants in hostile environment sexual harassment cases. Particularly after the Court's rejection of a "serious psychological harm" requirement in favor of a "totality of the circumstances" test in Harris v. Forklift Systems, Inc., 114 S. Ct. 367 (1993), plaintiffs must clear an amorphous but de minimus test in establishing that they have been harmed. A qualitative account of intersectional discrimination gives complex claimants - those who are specifically targeted or who have a disparate re- 
The stereotype of the promiscuous black woman is a vehicle for race discrimination, in that it racializes its sexual subject by reference to a dehumanizing image; and it is a vehicle for gender discrimination, in that it ascribes a form of stigmatized sexuality to the female portion of a particular race. But it is also a terrain on which race and gender discrimination come together to reinforce and, by particularizing, reshape each other.

b. Protected categories and characteristics. A social constructivist emphasis also underlies the second change that would be necessary to incorporate the complex subject in Title VII law: a change in the understanding of the characteristics that statutory categories protect. The assumption implicit in the Title VII regime is that membership in protected categories is biologically conferred and therefore unambiguous and stable over time. Legal actors must come to understand that biologically based qualities acquire their meaning through a process of social construction - through the practices and self-understandings of group members, the corrosive images of systems of discrimination, and a range of other influences - and the complexities of this process create far more variation and ambiguity than current doctrine assumes.

Understanding characteristics such as gender or race as given meaning largely through social interaction has several implications. First, membership in a protected category arises, not simply through possession of a biological trait, but also through manifestation of social practices or qualities that have come to be associated with it. ${ }^{198}$ As a result, there is more ambiguity as to who belongs in particular categories, because there are more indices of what constitutes group membership or identity and more ways in which these social and biological indices can intersect with each other. Second, discrimination can be quite various in the kinds of attributes that it targets: while some forms of discrimination follow the biological trait, others are tied to its social manifestations, and still others

sponse to a general practice, such as the display of particular kinds of pornography in the workplace - a particularly illuminating means of explaining how and why they have been harmed.

198. It might, quite reasonably, be argued that the language of the statute, including the use of terms such as sex and race, as well as salient portions of the legislative history, evince an intent to protect biological characteristics rather than those produced by social construction. I would note, however, that Title VII decisions on sexual harassment and the discriminatory operation of stereotypes, see infra section III.B.2, have acknowledged the difficulty of separating biologically given characteristics from socially constructed qualities that overlay them, as well as the need to address cases involving both. My approach would simply extend this insight from these areas into the mainstream of Title VII law. It does not depart so far from statutory language or original understandings as to endorse a pure theory of the social construction of gender or race. 
track the intersection of the biological with the social. Women are sometimes stigmatized on the basis of their sex - that is, simply because they are not men - but they may also be stigmatized for manifesting characteristics that are socially female. ${ }^{199}$ Men may also be stigmatized if they combine biological masculinity with socially female characteristics, such as emotionalism or sensitivity to sexual conduct. ${ }^{200}$ Women, on the other hand, may be less severely stigmatized if they manifest socially male characteristics, such as an exclusive career focus in the workplace. But biological "outsiders" are not always assured of protection by assuming the characteristics of the socially dominant group. The interest of many social groups in preserving the meanings made intelligible by social practices, and the interest of dominant groups in preserving the power conferred on them by the comparative valuation of such practices, means that sanctions may be imposed on biological group members who attempt to escape from the social characteristics ascribed to their groups. ${ }^{201}$ These factors mean that who may be considered a woman or a black for purposes of Title VII scrutiny is a multifaceted question, capable of contextually variable answers. ${ }^{202}$

The understandings elaborated above would permit courts to respond more fully to categorically ambivalent claimants. ${ }^{203}$ First, they would make clear that categorical ambivalence, such as that

199. Christine Littleton refers to the first as "sex discrimination" and the second as "sexual subordination." See Littleton, supra note 185, at 1045-46.

200. Littleton refers to this phenomenon, which may target either men or women who break free of the social-role expectations associated with their biological sex, as "gender oppression." Id. at 1045; see also Chamallas, supra note 127, at 126-29 (discussing the sexual harassment of Goluszek).

201. For an incisive, nuanced discussion of "disciplinary" harassment - violence or discrimination aimed at punishing the transgression of socially specified gender roles - see DunCan Kennedy, Sexy Dressing Etc. 147-62 (1993). For discussions of homophobia as a means of disciplining departures from social expectations associated with gender, see Fajer, supra note 86 , and Law, supra note 86.

202. This kind of variable understanding of the meaning of statutory categories might be viewed as an implementation of Angela Harris's injunction to make the multiplicity of identity visible by employing categories that are "explicitly tentative, relational and unstable." Harris, supra note 18, at 586.

For a wonderfully nuanced view of the possible interactions between biology and social context, or in the author's terms "essentialism" and "constructivism," in creating the category homosexual, see Janet E. Halley, Sexual Orientation and the Politics of Biology: A Critique of the Argument from Immutability, 46 STAN. L. REV. 503, 556-68 (1994).

203. These understandings would address the first (the biological character of protected traits makes group membership fixed and unambiguous), third (actions or judgments paradigmaticaliy understood as discrimination are not applied to members of the same group), and fourth (discrimination as a workplace-specific barrier rather than as part of a larger system of discrimination that helps to construct the subject) of the assumptions that have complicated the resolution of cases involving categorically ambivalent claimants. 
described by Scales-Trent, ${ }^{204}$ is not an anomaly but a form of subjectivity that occurs all the time. Because they possess biological and social characteristics that admit of ambivalence within themselves and in combination, it is not unusual for people to manifest, in juxtaposition or combination, qualities assigned to different sides of a race or gender dichotomy. Nor, moreover, is it unusual to see discrimination aimed at different bases of a raced or gendered identity. A brief perusal of any set of sexual harassment cases suggests that women are sometimes harassed in response to their biological sex, ${ }^{205}$ at other times harassed in response to their manifestation of socially female characteristics, ${ }^{206}$ and at still other times targeted for their divergence from socially female characteristics. 207 Courts have rarely felt compelled to look into these distinctions, because the recurrent factor, biological sex, is taken - often incorrectly to explain all varieties of abuse. If they were to do so, they would see patterns of discrimination that would justify enforcement in cases like Goluszek. The illumination of such practices as stigmatizing the social practice - notwithstanding its separation from the biological characteristic - or disciplining departures from race or gender norms can help place discrimination against categorically ambivalent claimants within the wider discriminatory patterns that Title VII targets.

204. In Scales-Trent's account itself, the ambivalence is not simply biological, in the form of a mixed-race heritage reflected in light skin, although that is the ambivalence that is immediately apparent to observers. It is also social: for example, she feels equally drawn to both gospel and classical music, an ambivalence she ascribes to her upbringing. See Scales-Trent, Commonalities, supra note 26, at 308.

205. Examples of this type of case frequently come from blue-collar work settings, where women who are recent entrants into a particular workplace are harassed without regard to their particular personal characteristics, as an expression of male workers' belief that women should not be doing this kind of work. See, e.g., Hall v. Gus Constr. Co., 842 F.2d 1010 (8th Cir. 1988) (considering the physical harassment of women on a road crew and their co-workers' characterization of them as "fucking flag girls").

206. These cases are harder to identify, as such women do not necessarily stand out in their work environment as it is depicted in the court's rendition of the facts. There are cases, however, in which a specific woman is targeted in the workplace and that woman appears to be particularly sensitive to sexualized conduct in the workplace. See, e.g., Bennett v. Corroon \& Black Corp., 845 F.2d 104 (5th Cir. 1988) (addressing the claim of a woman who was obscenely depicted on the walls of a men's room at her place of employment and who was particularly sensitive to sexualized conduct in the workplace), cert. denied, 489 U.S. 1070 (1989). Although it is possible that harassers could be targeting such a woman with a generalized desire to irritate the sensitive, quite apart from gender-role expectations, it seems more likely that this stigmatization of a kind of sensitivity frequently associated with gender is a devaluative response to a gendered characteristic.

207. See Rabidue v. Osceola Ref. Co., 805 F.2d 611 (6th Cir. 1986), cert. denied, 481 U.S. 1041 (1987); Ukarish v. Magnesium Elektron, 31 Fair Empl. Prac. Cas. (BNA) 1315 (D.N.J. 1983). 


\section{Statutory Strategies}

Title VII presents a unique kind of challenge to those who would implement the understandings elaborated above. Its enforcement has been strongly identified with a liberal, equality-based account of discrimination and determinate, biologically based conceptions of statutory categories. Yet if an understanding of discrimination as devaluation and a view of protected characteristics as socially as well as biologically derived has not developed within the dominant interpretation of the statute, it has not been wholly absent from Title VII doctrine. Cases concerned with sexual harassment, stereotypes, and disparate impact claims reflect elements, or seeds, of these understandings. With proper interpretation, such caselaw might be used to introduce the more systematic changes that would permit courts to accommodate complex subjects.

Sexual harassment cases, as well as cases involving the operation of stereotypes, ${ }^{208}$ reflect a promising point of departure, for several reasons. In these contexts, the elements of a Title VII claim that demand reinterpretation are writ large on the face of the case. The discriminatory judgments, disguised or oblique in many cases, are vividly rendered in the language or conduct of the perpetrators; the constructive force of oppression and the way that gender reflects an amalgam of biological and social factors are highlighted by the interactions of harassers and their targets. More importantly, these cases present one of the few contexts in which the background assumptions necessary to accommodate complex subjects have begun to appear in doctrine. Sexual harassment doctrine, like disparate impact law, ${ }^{209}$ illuminates relationships between discrimination in-

208. Cases involving allegations of stereotyping in hiring, promotion, and firing decisions present a mixed picture in terms of their accommodation of complex claimants. Madeline Morris has argued persuasively that courts are able to recognize the operation of single gender-related stereotypes but fail to recognize or respond to the operation of multiple or intersectional stereotypes. Morris, supra note 44. Morris argues, for example, that the courts were able to recognize the expectation of femininity that hindered the plaintiff in Price Waterhouse v. Hopkins, 490 U.S. 228 (1989), as a form of gender discrimination, but they were unable to draw the same conclusion about the intersectional stereotyping - as an "old Jewish mother" type - that may have led to the termination of the plaintiff in Fertig v. B'nai B'rith Hillel Found., No. CJV-79-607E, 1987 U.S. Dist. LEXIS 14291 (W.D.N.Y. Apr. 11, 1987). See Morris, supra note 44, at 260-65. It is possible, however, to characterize Hopkins, not only as a case involving a singular stereotype, but as a case involving a categorically ambivalent claimant: a biological woman who lacked conventional femininity in dress and deportment. See supra note 121 . Considered in the latter light, Hopkins sounds a more hopeful note for the prospects for legal accommodation of complex claimants.

Although the current judicial approach in this area is mixed at best, I see cases involving stereotypes as fertile ground for the cultivation of alternate understandings of discrimination, for the reasons elaborated below.

209. As I note supra in note 174 and accompanying text, disparate impact law reflects an effort to connect discrimination in the workplace to broader social patterns that may be use- 
side and outside the workplace. To the limited account of benign exacerbation of otherwise restricted opportunities offered by disparate impact law, sexual harassment doctrine adds scenarios in which perpetrators play more explicitly on socially created vulnerabilities or recreate within the workplace restrictive or oppressive gendered roles. Moreover, the analytic vehicle of the "reasonable woman," though no longer the applicable legal rule, reflects the receptivity of the doctrine to accounts of the social construction, through oppression and other influences, of the legal subject. In the stereotype cases, exemplified most recently by Price Waterhouse v. Hopkins, ${ }^{210}$ one sees the way that discrimination tracks social characteristics as well as, or in conjunction with, biological ones. In both contexts, one witnesses the ingeniously differentiated character of devaluation - the way a similar judgment or urge can operate differently against different subsets of a group.

The first part of the reinterpretive work to be done in these cases involves making explicit the elements of doctrine that depart from the dominant understanding. Cases should explain, for example, that sexual harassment is actionable because it replicates, and relies upon for the efficacy of its subordination, forms of sexual domination and gender devaluation that pervade society outside the workplace. Some courts have taken a step in this direction, explaining that sexual harassment reflects the exploitation of the vulnerable position of the plaintiff's group ${ }^{211}$ or that it creates a different impression on women than on men because of their relative experiences of sexual coercion in the larger society. ${ }^{212}$ These explanations need to be sharpened, as they have been in the work

ful in introducing a more constructivist understanding of discrimination. But because disparate impact cases may be cases involving no discriminatory or devaluative motivation - in which the prima facie case is made largely by reference to numerical showings - these cases may be less effective than sexual harassment or stereotyping cases for illuminating the new understandings of discrimination and group membership that will be most helpful in encouraging judicial accommodation of complex claimants.

210. 490 U.S. 228 (1989).

211. See, e.g., Goluszek v. Smith, 697 F. Supp. 1452, 1456 (N. D. Ill. 1988). Unfortunately, the Goluszek court failed to resolve the case according to this useful observation, because it assumed that the vulnerable group could only be biologically defined.

212. See Ellison v. Brady, 924 F.2d 872, 879 (9th Cir. 1991) ("For example, because women are disproportionately the victims of rape and sexual assault, women have a stronger incentive to be concerned with sexual behavior. Women who are victims of mild forms of sexual harassment may understandably worry whether a harasser's conduct is merely a prelude to violent sexual assault." (footnote omitted)). Although the court's language - highlighting incentives and understandable worries - evokes the autonomous liberal subject more strongly than the subject of social construction, the understanding that systematic oppression shapes the state of mind of the victim is unmistakable. 
of commentators, ${ }^{213}$ to highlight the explicit parallels between harassing treatment and the kinds of sexualized devaluation that women receive outside the workplace, ${ }^{214}$ and the effects that such treatment may produce on women's self-conception. Such an understanding locates employment discrimination as part of a larger system of discrimination that is potentially influential in the construction of the subject. Judges should also note, to the extent that they can discern it from the context, when sexual harassment appears to target something beyond biological femaleness: for example, a manifestation of socially female traits or a departure from specified gender roles. In Rabidue v. Osceola Refining Co., ${ }^{215}$ the court observed that the plaintiff, a particular target of the alleged harasser, was loud, assertive, and abrasive. ${ }^{216}$ It might also have noted that the distance between these qualities and socially female role expectations made the plaintiff a more likely target for disciplinary abuse. Identifying such characteristics makes the varied basis of gender identity - and the varied targets of discriminatory animus - more apparent. Such efforts begin the revision of those assumptions that impede response to complex claimants.

The second part of the task lies in naming, with as much specificity as possible, the practices one finds in cases involving complex claimants. Just as sexual harassment cases once made clear that what was at one time viewed as horseplay or a part of the job description was, in fact, discrimination, these cases must now make clear that what look like partial attacks on a subgroup are, in fact, particularized expressions of a further-reaching gender animus. ${ }^{217}$

213. See, e.g., MACKINNON, supra note 123 , at $18-23$ (stating that many traditionally female jobs are defined so as to impose on women the same sexually inflected roles they occupy outside the workplace); GUTEK, supra note 3, at 15-16 (citing the phenomenon of "sex role spillover," which involves treatment of women according to roles through which they are perceived outside the workplace, sometimes including elements of sexual construction or sexual devaluation).

214. There may be some tension between emphasizing the connections between workplace and societal discrimination, on the one hand, and, on the other, arguing for the inclusion within Title VII doctrine of plaintiffs like Goluszek, who, as men, are subject to a different social experience. In some sense, this tension may perform a useful regulatory function, because Title VII should be available to combat a kind of gender discrimination that operates far more frequently against women. In cases of men like Goluszek, however, it may be possible to argue - to a greater or lesser degree depending on the case - that a man who demonstrates a substantial constellation of socially female characteristics is likely to have been subjected to varied forms of social discrimination outside the workplace.

215. 805 F.2d 611 (6th Cir. 1986), cert. denied, 481 U.S. 1041 (1987).

216. 805 F.2d at 615.

217. See, e.g., Brooms v. Regal Tube Co., 881 F.2d 412 (7th Cir. 1989), overruled in part by Saxton v. American Tel. \& Tel. Co., 10 F.3d 526 (1993); Hicks v. Gates Rubber Co., 833 F.2d 1406 (10th Cir. 1987); Clay v. BPS Guard Servs., Inc. No. 92 C 2127, 1993 U.S. Dist. LEXIS 8399 (N.D. Ill., June 18, 1993). 
Advocates must argue, and judges must come to understand, that sexual derision, epithets, or threats are no less actionable or typical when they take a more particularized focus; on the contrary, the stigmatization of attractive women or blue-collar women or assertive women or pregnant women is in many cases simply animus toward women, expressing - and often camouflaging - itself by conforming to the characteristics of a particular target. This conclusion becomes apparent when one surveys sexual harassment cases in the aggregate, but the insight must also be reflected in the resolution of the individual case.

This strategy also requires that the compound forms of derision implicit in the harassment of women of color be identified and explained. Courts resolving such cases must specify that terms such as nigger bitch reflect both race and gender discrimination. They should be treated as additive in the sense that harassment of this type could give rise to recovery on either ground, thus foreclosing the kind of unidimensional resolution epitomized by Clay or Brooms. ${ }^{218}$ But they should also be recognized as interactive or intersectional, in the sense that such terms would never be applied to white women or to black men; the aggregative understandings of cases such as Hicks should not be permitted to define the phenomenon. Finally, this strategy means clarifying, whenever possible, that gender animus goes beyond associating biological traits with inborn incapacities. Such animus may also mean associating biological traits with certain socially prescribed roles and sanctioning departure from those roles through stigmatizing behavior. Courts and advocates should identify the derision - or in cases such as Hopkins, the application of stereotypes ${ }^{219}$ - that reflects this kind of

218. Interpretation of the rule regarding the original EEOC charge in such cases should be liberalized so that charges regarding intersectional discrimination originally brought as either race or gender claims could be extended to include the other category when filed as Title VII suits.

It is, of course, possible that in some cases there will be insufficient evidence of pervasive harassment as to one of the two categories of discrimination, although the plaintiff's claim may allege some epithets that should properly be regarded as both. The plaintiff's attorney in Brooms, for example, may have believed that this was the case - although, on the facts related, I would tend to disagree. Even when such an outcome is likely, however, it would be advantageous for courts and advocates to illuminate the intersectional character of any derogation that is specifically targeted at women of color; this will build the awareness that will permit such claimants to prevail on either ground in cases in which harassment was pervasive in both respects.

219. Both the district court and Supreme Court opinions in Hopkins were quite explicit in identifying the operation of gender-role expectations and stereotypes in Price Waterhouse's decisionmaking process. See Hopkins v. Price Waterhouse, 618 F. Supp. 1109, 1117 (D.D.C. 1985) (highlighting advice to the plaintiff to "walk more femininely, talk more femininely, dress more femininely, wear make-up, have her hair styled, and wear jewelry" as indicating a sex-role stereotype of a successful woman worker, and noting that female part- 
disciplining behavior. Not only would such doctrine make recovery easier for women like Ann Hopkins and Vivienne Rabidue, whose behavior departed from socially specified gender expectations of passivity, charm, or deference; but it would also help courts to understand when less familiar forms of gender discrimination are involved, as in the harassment of men like Goluszek and Polly.

The standard hiring, firing, and promotion cases offer more ambivalent terrain for implementing change. Decisions in these areas, as we saw above, have sometimes vindicated the claims of complex claimants. Yet a failure in these cases to elaborate a theory of the discrimination that justifies recovery has made the emerging doctrine of cases such as Jefferies and Walker subject to arbitrary restriction. One difficulty may be that these are largely disparate treatment cases; they draw on a body of Title VII law that conforms most closely to the dominant understanding of discrimination, and they have been most insulated from conceptual innovations in the understanding of discrimination. As the understandings that permit the full accommodation of complex claimants are elaborated in areas such as sexual harassment, however, it may be possible to apply them so as to broaden and enrich the disparate treatment area as well. For example, a decision like Jefferies could be supported by an argument that confirms the centrality of the sex-plus doctrine, on the ground that the particularization and variability of genderbased devaluation is one of the greatest sources of its durability and power. This understanding could make forms of discrimination that target a subgroup of a protected category a particular object of Title VII enforcement, unsubordinated to more general assaults on women as a group and not subject to the idiosyncratic restriction of cases like Judge v. Marsh. Cases such as Walker could be strengthened with highly particularized accounts of intragroup discrimination. As employment discrimination comes increasingly to be understood as exacerbating, exploiting, or replicating social patterns of group-based oppression, it may become easier to explain the relation between race and color, or the ways in which intergroup hierarchies may be reproduced within particular groups. Informed by such understandings - developed first in more hospitable bodies of Title VII doctrine - enforcement in same-

nership candidates at Price Waterhouse were viewed favorably if "partners believed they maintained their femininity while becoming effective professional managers"), modified, 825 F.2d 458 (D.C. Cir. 1987), revd., 485 U.S. 933 (1988); Price Waterhouse v. Hopkins, 490 U.S. 228,256 (1986) ("It takes no special training to discern sex stereotyping in a description of an aggressive female employee as requiring 'a course at charm school." "). 
group cases will no longer appear anomalous or in tension with primary enforcement objectives under the statute. ${ }^{220}$

*** $*$

Encouraging judicial responsiveness to the complex claimant speaks first to the needs of those who have struggled from the margins of their respective groups. Yet it also promises to broaden dominant understandings of discrimination and to help a laudably flexible statute to confront more fully the patterns of oppression shaping life and work in this society.

220. One might ask whether scarce energy and resources should be devoted to cultivating greater judicial solicitude toward male Title VII claimants, when Title VII enforcement has not yet succeeded in making many workplaces sufficiently hospitable toward women. As I suggested above, the framing of this question reflects a biological essentialism that I hope to call into question. A focus on the categorically ambivalent claimant - male or female will ultimately be of service to women by illuminating new understandings of discriminatory treatment and of what it means to be a member of the group women. Moreover, there is little in the highly contextualized emphasis on men reflecting socially female characteristics who have been victimized by more conventionally masculine supervisors or co-workers that will contribute to making the kind of red herring dreamed up by Michael Crichton paradigmatic. See Michael Crichton, Disclosure (1993) (depicting a female executive's harassment of a male under her supervision). 